\title{
A Evolução Recente do Espaço Financeiro no Brasil e Alguns Reflexos na Cena Política*
}

\author{
Roberto Grün
}

$\mathrm{O}$ primeiro ano do governo Lula surpreendeu a muitos pela rígida ortodoxia aplicada na direção da economia. Agradando aos "mercados", a conduta rapidamente desfez a bomba da profecia (auto-realizante) da "argentinização" do Brasil ou da "De-La-Rualização" de Lula. Incomodando os adeptos de Fernando Henrique Cardoso, foi chamada de "plágio mal feito" ou ironizada pelos séqüitos do grupo que esteve no poder na quadra passada. Por outro lado, a política econômica foi vista de maneira muito enviesada por diversos membros notórios do grupo que, ao menos para o público, estava mais próximo do então candidato Lula. Além do desconforto por ela mesma, ficou também fortemente sugerido que o caminho da ortodoxia financeira impedia qualquer política social ou setorial consistente. O espanto não foi evidentemente individual. Ele ecoava a apreensão de setores das classes médias que esperavam do governo petista

\footnotetext{
* Agradeço à Fundação de Amparo à Pesquisa do Estado de São Paulo - FAPESP e ao Conselho Nacional de Desenvolvimento Científico e Tecnológico - CNPq pelo financiamento das pesquisas que propiciaram o presente artigo. Agradeço também a leitura estimulante de Mauro Zilbovicius, Eduardo Noronha e dos pareceristas anônimos de Dados, bem como as sugestões de Afrânio Garcia, Frédéric Lebaron e Marie-France Garcia a versões anteriores apresentadas na École des Hautes Études en Sciences Sociales durante o período em que lá permaneci financiado pela Coordenação de Aperfeiçoamento de Pessoal de Nível Superior - CAPES. Evidentemente, sou o único responsável pelo texto.
}

DADOS - Revista de Ciências Sociais, Rio de Janeiro, Vol. 47, n-1, 2004, pp. 5 a 47. 


\section{Roberto Grün}

uma conduta que aliviasse a enorme pressão que os grupos prejudicados pela expansão do espaço financeiro na sociedade brasileira têm sofrido na última década.

Procurarei mostrar que a "surpresa" pode ser entendida sociologicamente como efeito de uma homologia de posições. Ela vinha sendo engendrada em períodos anteriores na prática cotidiana de diversos grupos de atores ligados ao Partido dos Trabalhadores e fazia-se lado a lado com outros desenvolvimentos na esfera das elites, em especial as econômicas. Assim, o fenômeno corresponde a uma evolução da sociedade brasileira, em especial a uma recomposição e diferenciação de suas elites, que é resultado da interação, não integralmente percebida como tal nas suas conseqüências em termos de integração de perspectivas, de ordens de atores situados em subespaços aparentemente antagônicos do tabuleiro político e social.

Para afirmar a análise, trarei evidências das atividades legislativa e financeira, do espaço da previdência privada e do relacionamento dos atores políticos com os econômicos. As evidências surgem: (1) do comportamento dos agentes e do resultado de suas interações em processos que dizem respeito à tramitação de aspectos da legislação financeira; (2) da análise da face pública de alguns empreendimentos econômicos ligados direta ou indiretamente à onda de privatizações deflagrada por Fernando Henrique Cardoso; e (3) de um contraponto geral, vindo dos resultados de pesquisas recentes no universo em contração das organizações brasileiras.

No espaço intelectual, o trabalho pretende ser um exercício de sociologia econômica, em especial, do ramo dessa especialidade que se ocupa das questões financeiras. Os últimos anos assistiram ao desenvolvimento de um novo subespaço nas ciências sociais, chamado de "estudos sociais das finanças". Em torno dele estão se congregando dois grupos de autores: o primeiro diz respeito a nomes conhecidos da sociologia econômica e o segundo, de cientistas mais ligados aos estudos sociais sobre a ciência. As duas ordens de analistas registram a centralidade das articulações financeiras na definição dos contornos da sociedade contemporânea. Em seguida, cada uma delas tenta pôr para funcionar as idéias centrais da respectiva modalidade de origem para penetrar cientificamente naquele espaço. Grosso modo, a corrente analítica originária da sociologia econômica reivindica o prosseguimento do caminho iniciado na obra seminal de Polanyi 
(2001 [1944]). Este autor inaugura um veio analítico que desenvolve a idéia da construção social dos mercados como ponto de entrada e como a afirmação da relevância de um ponto de vista sociológico para os fenômenos normalmente estudados exclusivamente pelos economistas (Garcia, 1986; Callon, 1998).

Por sua vez, o pessoal oriundo dos estudos sociais da ciência procura utilizar o ferramental de estudos de rede, desenvolvido originalmente para dar conta da construção da veracidade e aceitação de enunciados científicos ${ }^{1}$. Aí, mais do que evidenciar as suas condições sociais de existência, como procura fazer a primeira corrente, a pretensão é de "abrir a caixa-preta" do mundo das finanças para explicar seu funcionamento. Tentando utilizar as duas vertentes, o objetivo teórico deste artigo é mostrar a pertinência do enfoque da "sociologia das finanças" para a compreensão do Brasil contemporâneo.

Os primeiros desenvolvimentos isolados de cada um dos grupos internacionais que se ocupam do tema estão convergindo institucionalmente para espaços de diálogo virtuais ${ }^{2}$ e analiticamente para a recuperação parcial do antigo programa da FinanzSociologie (Guex, 2003), do início do século XX, de que Schumpeter (1991) foi talvez o representante mais conhecido no presente. Trata-se, aí, justamente de mostrar que os desenvolvimentos ocorridos ou em curso na esfera financeira são uma espécie de construção do esqueleto ou da infra-estrutura em torno da qual a sociedade, em especial as suas elites, está encontrando ou encontrou um novo molde para se conformar. Nas palavras de Schumpeter:

"As finanças são um dos melhores pontos de entrada para estudar os mecanismos sociais, em particular, ainda que não exclusivamente, os mecanismos políticos. A fecundidade desse ponto de vista se revela justamente nos momentos, ou melhor, nas épocas de mudanças, quando o presente começa a morrer e a se transformar em alguma coisa de novo" (idem:101).

Assim, o estudo do espaço das finanças pode conduzir-nos a uma aproximação do que Bourdieu (1989) chamou de "campo do poder": o lócus social no qual as diversas elites ou, na linguagem do autor, os pólos dominantes dos diversos campos, mais ou menos autônomos, se encontram, gerando formas mais ou menos regradas de convívio por meio do estabelecimento de critérios de equivalência para os valores dos "capitais" de cada grupo ${ }^{3}$. 


\section{Roberto Grün}

A sociologia das finanças, nos seus dois ramos, acaba dando uma pista forte para as formas por meio das quais o consenso sobre as taxas de câmbio se constrói, corroborando a idéia de que em torno do léxico das finanças se construiu uma espécie de língua franca das elites contemporâneas que, entre outros efeitos, acaba redefinindo a ordem de prioridades das agendas societais modernas (Boyer, 2002). No cuore do gênero de análise aparece a sua preocupação mais central, que é justamente a de explicitar o caráter mimético dos processos cognitivos que informam as decisões dos agentes financeiros. Este veio aparece como uma contraposição direta ao pressuposto maximizante, que é central na explicação econômica do comportamento dos indivíduos nos mercados. Dessa maneira, o mundo das finanças recebe um tratamento que pode ser considerado uma evolução do programa da construção social da realidade da sociologia do conhecimento dos anos 60 (Berger e Luckmann, 1966). A abordagem explica como, dados os novos suportes informáticos advindos do estabelecimento e uso da rede mundial de computadores, os corretores de câmbio acabam produzindo um novo nível de realidade (virtual?) no seio da qual as notações (ratings) estabelecidas pelas agências de risco acabam se tornando um ponto de referência comum obrigatório e, ainda que amplamente insatisfatórios como representação acurada da realidade econômica dos países ou empresas que eles classificam, terminam por direcionar os comportamentos dos membros da comunidade financeira internacional, com os efeitos já sabidos sobre o destino de milhões de indivíduos em todo o mundo (Knorr Cetina e Bruegger, 2002a; King e Sinclair, 2003). E, mais do que isso, a abordagem contribui para elucidar os mecanismos por meio dos quais as crises desencadeadas pela hipertrofia do espaço das finanças acabam sendo "patrocinadas" pela sociedade, a qual, temendo os seus "efeitos sistêmi$\cos ^{\prime \prime}$, generosamente banca os excessos da especulação, absorvendo o seu custo, nas freqüentes operações de salvamento das manobras financeiras malsucedidas, como foi o caso do fundo Long-Term Capital Management-LTCM${ }^{4}$ no final da década passada (Mackenzie, 2003).

O grupo "construção social do mercado", o outro ramo de origem da especialidade, trata o mimetismo por um viés que normalmente é catalogado como um neo-institucionalismo sociológico (Powell e Dimaggio, 1991). Neste caso, fala-se mais de isomorfismo e buscam-se os constrangimentos sociais que induzem as organizações ou indivíduos ao comportamento imitativo. A abordagem é mais presente, e 
mesmo tradicional, na análise das organizações. Ela passou a se interessar pelos aspectos financeiros da realidade econômica, provavelmente impressionada pela centralidade que o ponto de vista financeiro ganhou recentemente na definição dos destinos das empresas (Dimaggio, 2001; Fligstein, 2001). No espaço que nos interessa agora, esse gênero de análise irá, por exemplo, mostrar que os gerentes de fundos de investimentos, ligados ou não a fundos de pensão, estão mais preocupados em evitar erros pelos quais eles seriam responsabilizados em termos judiciais, organizacionais ou, no plano da reputação, como depositários infiéis, do que em "acertar na mosca", trazendo rendimento ótimo para as aplicações que realizam. Assim, é preferível seguir o comportamento dos demais agentes do mercado, mesmo quando o agente em questão desconfia que esse não é o melhor caminho, do que correr o risco de ser responsabilizado por conduta aventureira ${ }^{5}$. De maneira geral, as duas abordagens acabam chamando a atenção para a dificuldade de um agente individual agir na contramão do consenso estabelecido por essa arena social que é o mercado financeiro, principalmente em momentos de euforia como os períodos de crescimento vertiginoso dos valores bursáteis, que, como a experiência mostra, antecedem quedas igualmente vertiginosas (Galbraith, 1998). Dessa maneira, o caráter sacrossanto da hipótese da racionalidade dos agentes fica bastante comprometido (Boyer, 2002; Mackenzie, 2003).

Outro ponto que deve ser salientado é a chamada teoria do "Estado mínimo" (Guex, 2003). A sociologia econômica, em especial o ramo da construção social do mercado, tem seu fundamento moral na luta contra a transformação dos Estados de Bem-Estar Social construídos no pós-guerra dos países desenvolvidos. A economia financeira, que afiança intelectual e operacionalmente aquele desenvolvimento, constrói uma nova idéia de como devem comportar-se as finanças públicas, em contraposição ao fundamento keynesiano do Estado de Bem-Estar Social. Dando conta das políticas, aparentemente sem sentido, de produção de déficit fiscal perseguidas pelos governos republicanos dos EUA a partir de Reagan e em especial o último Bush, surge o enunciado de que o Estado deve estar permanentemente deficitário para, por meio da repactuação contínua de suas dívidas com os mercados financeiros, voltar a ser controlado pelos setores que perderam a primazia absoluta da sua condução ${ }^{6}$. Esse controle se teria per- 


\section{Roberto Grün}

dido com a democratização crescente e a diferenciação de interesses que começou no pós-guerra e se ampliou a partir dos anos 60.

A doutrina professada pela economia financeira predica que as riquezas da sociedade se tornam mais produtivas se estiverem nas mãos de particulares, e não do Estado ou das empresas. Afinal, só os indivíduos diretamente interessados na frutificação dos seus capitais são sistemáticos no objetivo de maximizar o lucro de suas aplicações. As grandes empresas sofrem do problema do gigantismo - seus gerentes, que controlam os processos decisórios internos por causa da assimetria de informações, teriam mais interesse em fazer as organizações crescerem para aumentar o seu poder pessoal do que em aplicar diligentemente o capital que lhes foi confiado pelos acionistas ${ }^{7}$. Da mesma forma, os Estados seriam presas inevitáveis de seus burocratas, que, analogamente, também prefeririam o crescimento dos aparelhos e, conseqüentemente, do seu poder, à eficiência no gasto público. O desenvolvimento da sociologia das finanças entraria na guerra cultural contemporânea procurando desvendar o fundamento ideológico das considerações acima. Ela abriria a caixa-preta das finanças, mostrando os interesses bem delimitados e parciais que estas alimentam, apesar da aparência (robusta) de representarem o interesse geral da nação ${ }^{8}$.

\section{O Espaço Empírico}

No caso brasileiro, acompanhei em primeiro lugar a disputa pela definição da configuração precisa dos fundos de pensão e, em seguida, a análise do poder locutório dos diversos grupos de atores que disputam e ao mesmo tempo contribuem para a institucionalização da governança corporativa. Acessoriamente, procurei referências sobre a tramitação legislativa de assuntos financeiros, como a possível limitação da taxa de juros e a lei de falências. Os dados colhidos desses objetos possibilitam uma visão - evidentemente parcial, como todas do campo do poder: esse espaço, ao mesmo tempo econômico, social e cultural, em que se definem atualmente os diversos caminhos pelos quais irá passar a evolução da sociedade brasileira nos próximos anos.

Fundos de pensão são uma realidade interna importante nos países anglo-saxões desde os anos 40, pelo menos. Nos países mais populosos da Europa continental, eles se tornaram um tema relevante nos 
anos 90, em parte pelo comportamento dos fundos anglo-saxões que passaram a ser investidores importantes nos mercados financeiros europeus, em parte pelas diversas tentativas de substituir o tradicional sistema de aposentadoria por repartição pelo sistema de aposentadoria por capitalização. Segundo a sabedoria convencional, este último é mais moderno e adequado para fazer frente ao "problema" do envelhecimento das populações ${ }^{9}$. Não é, assim, por acaso que a análise interna de seu funcionamento e de suas relações com os outros atores empresariais é mais desenvolvida na sociologia dos países anglo-saxões (Useem, 1993; 1996), enquanto o exame de suas possíveis conseqüências indesejáveis para o equilíbrio social é mais desenvolvido pelos cientistas sociais da Europa continental (Nikonoff, 1999; Lordon, 2000a; Sauviat, 2001).

A partir do início dos anos 90, assistimos a uma disputa acirrada pela direção dos fundos de pensão brasileiros (Grün, 2003c). Seus contendores eram: (1) os administradores tradicionais dessas entidades, que ali chegaram, em geral, vindos de remanejamentos nas altas posições nas empresas estatais que patrocinavam os fundos; (2) vários atores oriundos, na sua maioria, do braço sindical de classe média da Central Única dos Trabalhadores - CUT e da Força Sindical - FS (bancários, eletricitários, telefônicos, petroleiros, e também metalúrgicos); e (3) vários indivíduos provenientes dos mercados financeiros, em geral próximos aos novos bancos de investimentos que proliferaram na década passada.

Os primeiros atores "aterrissaram" nos fundos de pensão, em geral, como uma espécie de "prêmio de consolação" pela derrota em disputas internas na direção das grandes empresas estatais, que assim, no início, se transformaram em terras de exílio para aqueles profissionais. O aumento da importância dos fundos na economia brasileira e o intenso trabalho de construção identitária que esses agentes empreenderam a partir dos anos 80 acabaram criando uma nova identidade coletiva - na década de 90 , eles passam a se chamar de membros do "sistema" (da previdência privada).

Os atores vindos da galáxia sindical são atraídos pelo espaço representado pelos fundos de pensão justamente no período em que o surto grevista iniciado com a redemocratização política se arrefece (Noronha et alii, no prelo). Os fundos têm, estatutariamente, um conselho no qual devem estar presentes representantes dos cotistas da ativa e 


\section{Roberto Grün}

dos já pensionistas. Se, no início, essas posições eram pouco cobiçadas, rapidamente percebeu-se a sua importância, e as disputas pelos assentos tornaram-se cada vez mais intensas. Nesse contexto, a técnica eleitoral e a representatividade genérica dos quadros oriundos ou ungidos pelo movimento sindical passaram a mostrar a sua força diante das possibilidades de candidatos "avulsos" ou inspirados pelos membros do "sistema", que haviam sido os primeiros a ocupar aquelas posições.

Os atores ligados ao mercado financeiro aproximaram-se dos fundos de pensão a partir de duas motivações. Uma mais previsível e estrutural foi a tentativa de fazer grandes negócios ou obter comissões sobre o movimento das enormes massas de investimentos que os fundos realizam e refazem constantemente. Colocou-se aí a questão da terceirização das carteiras de investimentos, fenômeno em torno do qual se estabeleceu um contencioso: seriam os fundos de pensão capazes de gerir seus próprios ativos ou eles necessitariam da ajuda de "verdadeiros profissionais das finanças"? Muito além de uma simples questão prática a ser aferida aritmeticamente, estávamos diante de uma disputa identitária. Aceitando essa prestação de serviços como "natural", os fundos não só perdiam parte de sua independência, como também renunciavam à imagem de que seus gestores eram financistas tão capazes como aqueles que operavam no mercado tradicional ${ }^{10}$. A outra motivação, mais conjuntural e mais premente, estava ligada à necessidade manifesta do governo Fernando Henrique de contar com os capitais dos fundos de pensão para promover o processo de privatização das grandes empresas estatais. Como mostrou a seqüência de episódios da privatização da malha norte da Telebrás, depois batizada de Telemar, os fundos foram tangidos a aceitar parcerias com bancos de investimentos que dificilmente realizariam de maneira espontânea (Duailibi, 2001:A13). O constrangimento para a adoção das duas linhas de conduta poderia se dar indiretamente, compelindo os membros do "sistema" a agir de acordo com o demandado ou, na forma mais extrema, substituindo-os por indivíduos mais próximos aos desígnios da política econômica daquele momento. Os diversos episódios em torno da privatização da malha norte da Telebrás, que tiveram o ex-bancário, tornado operador financeiro e político, Ricardo Sergio como protagonista, tornaram essa situação praticamente pública (Santos, 2001:A9). 
De maneira geral, atravessávamos uma conjuntura na qual dois grupos de atores, cada um poderoso à sua maneira, desafiavam o "sistema": os financistas brandindo a espada do verdadeiro profissionalismo; os sindicalistas, a bandeira da verdadeira representatividade. No período da Presidência de Fernando Henrique Cardoso, não por acaso, preponderou a primeira impugnação, acrescida de uma deslegitimação constante dos fundos, sob a alegação de que eles eram "corporativos". Assim, o governo federal e alguns estaduais, coadjuvados por setores da imprensa de negócios, tentaram manter os administradores dos fundos de pensão sob vigilância cerrada e pressão permanente. O principal instrumento direto foi a Secretaria de Previdência Complementar - SPC, do Ministério da Previdência, que dava ênfase aos resultados das aplicações financeiras realizadas pelos fundos por via do estabelecimento de benchmarkings de resultados, mas que, proverbialmente, permanecia muda sobre a correição da forma de integração dos fundos nos grupos que participavam dos leilões de privatização. Se houve alguma ligação entre essas duas pontas da ação governamental - a insistência nos benchmarkings e no caráter "corporativo" dos fundos sendo usada para constranger os membros do sistema a aceitar as cláusulas leoninas que lhes foram impostas pelos bancos de investimento na conformação das sociedades de propósito único que se constituíram naquele momento -, isso a pesquisa histórica detalhada do período nos mostrará no futuro.

Na nova quadra inaugurada com a vitória de Lula em 2002, os sindicalistas que já atuavam na área da previdência privada serão ungidos em diretores executivos dos grandes fundos, sendo convidados a utilizar o patrimônio das entidades nas grandes empreitadas que o novo governo quer fazer deslanchar, como as parcerias público-privado (PPPs) em obras de infra-estrutura (Martinez, 2004:4-5) ${ }^{11}$. É bom deixar claro que essa ligação mais direta com as estratégias do novo governo também não é realizada en douceur, já que os atuais dirigentes dos fundos não deixam de manifestar suas reservas sobre o assunto e, além disso, os oponentes dos petistas na representação dos cotistas dos fundos não deixam de apontar esse possível atrelamento de suas poupanças a investimentos talvez não rentáveis ou seguros (Futema, 2004).

Um dos efeitos mais diretos da abertura dessa janela foi que esses agentes oriundos da vida sindical irão interessar-se pelas questões de gestão financeira e econômica de maneira genérica, criando-se aí um 


\section{Roberto Grün}

espaço de interlocução com as elites econômicas tradicionais. Nesse sentido, acompanhamos em especial suas posturas referentes aos problemas societários dos empreendimentos nos quais os fundos de pensão devem investir. O momento coincidiu com o da tramitação da nova Lei das Sociedades Anônimas, uma peça fundamental na tentativa de transformação do capitalismo brasileiro nos moldes requeridos pela modernização à norte-americana, preconizada pela academia e pelos órgãos de fomento econômico internacionais. Colocava-se aí o problema da instauração da "boa" governança corporativa, um modelo virtuoso de relação entre os mercados de capitais e as empresas, caracterizado pela transparência contábil e pelo respeito absoluto aos direitos estendidos dos seus acionistas. Esse tema, originalmente da economia financeira acadêmica e peça central nas tentativas de exportação do modelo anglo-saxão de capitalismo ${ }^{12}$, foi lançado pelos financistas e políticos próximos a Fernando Henrique durante seu governo sem que esses arautos tenham conseguido dobrar a resistência do "capitalismo tradicional", ou sem que esses atores tenham considerado que a questão fosse suficientemente importante para valer a pena confrontar seus oponentes no espaço das elites econômicas estabelecidas. Mas na voz dos sindicalistas, em especial dos ligados à CUT, sobretudo no período que precedeu as eleições presidenciais de 2002, preocupados em mostrar a adesão às práticas econômicas estabelecidas no mundo financeiro, o tema irá ganhar o estatuto de manifestação do interesse geral da nação. Nesse espaço, a governança corporativa foi considerada um instrumento fundamental para o desenvolvimento econômico moderno, pois criaria um clima propício ao investimento produtivo e seguro das poupanças dos trabalhadores brasileiros, principalmente aquelas coletivizadas pelos fundos de pensão, nas empresas e demais empreendimentos do país, que assim passariam a dispor de recursos para realizar seus projetos de expansão ${ }^{13}$.

Talvez o ponto mais interessante dessa configuração que está fazendo nascer a "boa governança corporativa tropical" seja a visibilidade que ela fornece sobre os diversos segmentos do espaço financeiro nacional e suas articulações com o mundo da política. Para nosso "teste de paternidade", a janela que foi aberta pela campanha eleitoral para a Presidência da República em 2002 é uma excelente oportunidade a ser utilizada. Desse ponto de vista privilegiado, pudemos ver a coexistência nem tão pacífica assim de vários "subespaços" financeiros, 
mais ou menos próximos ao entorno de Fernando Henrique Cardoso. Apesar de algumas tentativas erráticas desse governo em promover o mercado financeiro nacional ou regional, por intermédio da fixação da Bolsa de Valores do Rio de Janeiro como local para a realização dos leilões de privatização ou o reforço da Comissão de Valores Mobiliários - CVM, os grandes negócios envolvendo os arranjos e rearranjos daquele processo se faziam cada vez mais nas grandes bolsas mundiais (Nova Iorque, Londres, Frankfurt, Tóquio), privando os intermediários bursáteis locais de seu fundo de comércio, exceto justamente dos fundos de pensão, legalmente obrigados a aplicar seus recursos apenas no Brasil. O fenômeno do esvaziamento das bolsas de valores dos países periféricos amplia-se, no caso brasileiro, com o fechamento de capital de inúmeras empresas, tangidas pelos altos custos administrativos da manutenção do capital aberto e pelo pouco retorno em termos de obtenção de recursos novos que os mercados de capitais realmente propiciavam (Ciarelli e Farid, 2002).

\section{O GERAL E 0 PARTICULAR NA DIFUSÃO DA GOVERNANÇA CORPORATIVA NO BRASIL}

A "boa" governança corporativa é a solução internacionalmente reconhecida como o padrão do receituário neoliberal para resolver o problema da capitalização das empresas, fazer deslanchar não só os mercados financeiros, mas também as economias locais como um todo ${ }^{14}$. Os seus preceitos principais são assegurar a possibilidade de aquisição do controle das Sociedades Anônimas - SAs por meio dos mercados financeiros, a instauração da transparência contábil, o respeito absoluto dos acionistas minoritários e o fim das ações preferenciais (sem direito a voto). Ela tornaria atraentes os investimentos em papéis das empresas, e assim todos lucrariam: o país, que veria sua economia deslanchar; as empresas, porque ganhariam acesso a fontes de financiamento de longo prazo e baixo custo; os investidores, que teriam maiores garantias e liquidez para suas colocações e conseqüentemente maior rentabilidade; e, por fim, os administradores profissionais das empresas, além dos seus empregados em geral, que teriam seus rendimentos e interesse pelo trabalho elevados por causa da adoção de esquemas de remuneração variável, como as stock-options que costumam acompanhar a instauração da "boa" governança. Mas, se todos se beneficiam com ela, por que então a "boa" governança não se instaura? Na verdade, a governança pretendida torna a vida dos 


\section{Roberto Grün}

dirigentes das empresas realmente existentes mais trabalhosa e menos livre. Em primeiro lugar, obrigando-os a desfazer um tipo de arranjo societário já estabilizado. Ele acomoda bem as formas de transmissão de herança dos empresários: as ações com direito a voto de suas companhias eram cedidas aos grupos de herdeiros ungidos para dar continuidade aos empreendimentos, enquanto os preteridos deveriam contentar-se com títulos que lhes davam direito a rendimentos, mas sem capacidade de controle sobre os negócios - as ações preferenciais (sem direito a voto nas assembléias de acionistas), que muitos associam às populares "mesadas". Assim, fica claro explicar porque, enquanto aqueles a favor da "boa" governança agiam publicamente, com um fervor quase messiânico, desenhando a possível inovação como o próprio caminho da virtude para o capitalismo e a sociedade brasileiros (CVM, 2002:13), aqueles que se opunham o faziam em surdina, sem nenhum alarde, e concentrando seus esforços de convencimento junto àqueles que "realmente interessavam", na ante-sala do poder central (Mattos, 2001).

No espaço das finanças, doutrinariamente, todos são a favor da governança corporativa, que controlaria o comportamento oportunista dos dirigentes das empresas organizadas como SAs, que é, como vimos, um pressuposto teórico e ideológico do consenso atual. Afinal, as idéias do mecanismo legal da governança chegam até nós totalmente caucionadas pelos arautos da internacionalização financeira ${ }^{15}$. Contudo, as diferenças de ênfase talvez sejam mais importantes do que as semelhanças do discurso. Para os atores mais internacionalizados do mercado, normalmente portadores de diplomas e backgrounds construídos na interface entre o mundo acadêmico internacional e a prática profissional, paradoxalmente a questão é menor ${ }^{16}$. Capazes de operar nas grandes praças financeiras, eles podem prescindir, ao menos a curto prazo, do desenvolvimento horizontal das oportunidades de intermediação que a instauração da governança corporativa propiciaria. Já para os atores tradicionais, que normalmente são formados profissionalmente na prática direta do mercado e estão umbilicalmente ligados aos instrumentos financeiros internos e mais conhecidos do país, a questão é muito maior. Afinal, o crescimento dos primeiros pode dar-se a expensas dos segundos, tanto na intermediação tradicional, agora mais avisada, quanto na proposição de alternativas de investimentos mais sofisticadas, seja no Brasil ou nas grandes praças mundiais. 
Colocamo-nos, desse modo, diante da questão da diferenciação do mundo das finanças. Até o processo de conglomeração bancária patrocinado pelo regime militar, uma infinidade de pequenos intermediários avulsos convivia com os bancos estabelecidos. Progressivamente, eles foram perdendo espaço e os bancos comerciais transformaram-se em "supermercados financeiros", passando a administrar mais diretamente a poupança nacional. No período anterior, tínhamos a figura do corretor financeiro independente ou das pequenas companhias distribuidoras de valores mobiliários, que indicavam aos seus clientes, normalmente famílias de classe média, boas aplicações em títulos de renda fixa, como as letras de câmbio oriundas ou lastreadas em operações de crédito do comércio varejista, ou de renda variável, como as ações das empresas negociadas na Bolsa ou em lançamento, ao lado das aplicações em moeda estrangeira, estas em geral à margem da contabilidade oficial. Uma característica bem marcada da época era o tipo de relacionamento entre corretor e clientela, que se dava na base da confiança mútua, sem grande respaldo oficial, tendo como ponto-chave o fato de o corretor ser considerado honesto. Nesse sentido, na São Paulo "pré-monopolista", na qual os relacionamentos ainda tinham forte componente étnico, as reputações tinham muito a ver com o entrelaçamento comunitário, sendo freqüente encontrarmos os corretores em posições de destaque nas entidades dos seus grupos de origem ou religião, que davam lastro às suas reputações. $O$ entendimento básico era de que as aplicações financeiras eram consumo diferido em uma etapa mais pródiga da vida financeira / profissional das famílias que deveriam ser usadas em épocas mais difíceis ou em ocasiões especiais esperadas, como casamentos, grandes viagens, aquisições de imóveis etc. A partir dos anos 70, os bancos ${ }^{17}$ foram progressivamente estreitando o espaço para esse tipo de negócio, concentrando neles mesmos a gestão das poupanças. Esse processo diminuiu a clientela individual dos corretores independentes, que continuaram, entretanto, a agir em vários tipos de intermediação, muitas vezes em nome dos próprios bancos.

Os últimos anos assistiram à impugnação crescente do papel dos bancos comerciais na medida em que eles foram responsabilizados pela permanência das altíssimas taxas de juros praticadas no país. Fala-se, portanto, da necessidade de "desintermediação" das poupanças, já que os bancos obteriam margens de lucros excessivas pelo seu trabalho de coletar e reaplicar os recursos financeiros. Abriu-se então a 


\section{Roberto Grün}

possibilidade de instalação de muitos agentes avulsos na organização dessa corretagem, bem como se ensejou uma propensão à criação de novos instrumentos de liquidez, parcialmente fora da ação açambarcadora dos bancos, como os fundos de recebíveis que começam a disseminar-se na paisagem financeira ${ }^{18}$. Esses títulos, oriundos de vendas a prazo realizadas pelo varejo, seriam descontados a taxas elevadas se a empresa varejista se dirigisse diretamente ao banco para descontá-los. Os fundos de recebíveis permitem que os títulos sejam "securitizados" e repassados em lote para particulares ou empresas, devendo aceitar um risco que se torna uma espécie de média dos riscos desse gênero de operação. Em contrapartida, farão jus a um rendimento maior do que conseguiriam em uma aplicação de mesmo montante na rede bancária.

A "securitização", de alguma forma a extensão do princípio que criou as sociedades por ações para operações mais diversificadas, é o agrupamento dos títulos por algum critério de pulverização de risco, seguido da sua divisão em blocos homogêneos para serem vendidos aos tomadores interessados. É a base mesma do desenvolvimento das novas formas de crédito, dos novos produtos financeiros. A lógica é: (i) antecipar o resultado das operações para o vendedor e assim permitir que ele utilize o capital empregado em outras empreitadas; (ii) pulverizar o risco de cada operação de crédito individual, substituindo o mais incerto risco da inadimplência de um devedor particular por uma alíquota do risco, menos incerto, do conjunto dos devedores da empresa em questão; (iii) pulverizar o risco de operações muito grandes ou de resultado incerto, permitindo a sua realização, já que é mais razoável um investidor arcar com um risco elevado - e grande expectativa de ganho se a operação for completada - quando o valor dessa operação for pequeno em relação ao total de suas aplicações.

Por sua vez, a engenhosidade do financista consiste em ganhar uma comissão criando um papel (security) que seja aceito pelas "duas pontas", cuja taxa de desconto seja baixa para a empresa que originou o crédito - o nosso varejista - e a remuneração alta para quem irá comprar a security, cujo interesse é receber um título com risco baixo em relação à expectativa de lucro, tudo isso tendo como parâmetro as taxas cobradas e oferecidas pela rede bancária. Assim, descontados os aspectos referentes à percepção do risco das operações, quanto maiores forem as taxas bancárias, maior é o espaço para a criação de novos instrumentos extrabancários de antecipação de resultados e de cria- 
ção de liquidez em geral (a não ser que o governo coíba essa atividade financeira realizada à margem da rede bancária).

A outra grande ponta do desenvolvimento dos produtos financeiros é aquela que lida com a demanda das empresas por proteção contra o risco de alguma operação, em especial de câmbio. Entram em campo os chamados "derivativos" e "opções", títulos exarados da necessidade de as empresas se protegerem das flutuações, normalmente de câmbio, mas também de qualquer outro preço de mercadoria ou serviço que possa afetá-las (p. ex., o preço da soja para uma empresa que fabrica óleo de cozinha ou o preço do transporte para o escoamento da safra do mesmo produto). Vistos durante muito tempo como fonte de especulações desenfreadas ${ }^{19}$, que prejudicavam os produtores em benefício dos especuladores, esses tipos de papel tiveram sua circulação cerceada na maior parte dos países durante muito tempo, com legislações que atendiam ao clamor popular que costuma ser produzido em épocas de crise econômica (Mackenzie, 2002). A desregulamentação dos mercados financeiros internacionais que começou nos anos 90 deu sinal verde para uma nova onda de desenvolvimento desses papéis. Essa tendência tem reflexos importantes no espaço financeiro, já que a sua criação e comércio também exigem um nível de conhecimento de matemática financeira não corriqueiro. Daí se estabelece uma verdadeira barreira cultural de entrada para os candidatos às funções de corretagem, bem como uma espécie de expulsória para aqueles que não conseguirem adaptar-se rapidamente à nova tecnicalidade do ofício (Bernstein, 1992).

O período mais recente assistiu a um novo desenvolvimento da intermediação individual, que aqui deve ser entendida como oposta à intermediação bancária, tida como excessivamente onerosa. Em parte impulsionada pela desregulamentação internacional dos mercados financeiros que visa justamente diminuir os custos da intermediação, em parte por uma importante redefinição do métier, estamos assistindo ao desabrochar de novas figuras, em algum grau descendentes dos corretores da fase pré-monopolista, mas em outro pertencentes a uma espécie muito diferente. De novo os atores são independentes dos grandes conglomerados, de novo eles podem atender a particulares, mas o principal atributo que eles exibem não é mais a confiança, mas um novo tipo de competência técnica que surge na esteira da evolução da economia financeira ${ }^{20}$. Agora, perseguindo o objetivo de maximizar o rendimento possível para um nível de risco predeterminado 


\section{Roberto Grün}

(ou vice-versa), o agente financeiro maneja um sofisticado conjunto de técnicas de avaliação de retorno e risco para as aplicações, constituindo os chamados "portfolios otimizados", que se tornam tão mais imunes a problemas quanto mais diversificados forem os tipos de risco associados a cada um dos títulos que compõem a carteira ${ }^{21}$, daí uma das necessidades de os novos mercados terem à disposição alternativas mais diferenciadas de títulos mobiliários, como os recebíveis (Bernstein, 1992; Fligstein e Freeland, 1995; Mackenzie, 2003).

\section{O CAMPO DAS FINANÇAS: CONFLITOS E CONVERGÊNCIAS}

Na sua etnografia da City londrina, Paul Thompson (1997) sugere-nos que as transformações observadas na paisagem da intermediação econômica a partir dos anos 80 apresentam um forte componente de substituição de gerações. Também ali, não mais se encontra o corretor benevolente, que extrai a sua legitimidade diretamente do reconhecimento da honestidade, atributo que é quase sinônimo de origem social legítima (gentlemanly) e meia-idade, mas jovens agressivos, propondo negócios mais arriscados para uma clientela que, teoricamente, sabe dos riscos que está correndo e os aceita em nome de uma maior rentabilidade. E, aos atributos geracionais diretamente ligados ao conteúdo do trabalho, podemos, tanto no caso brasileiro quanto no inglês, acrescentar outros marcadores simbólicos que denotam a tentativa de registrar claramente a existência de uma descontinuidade entre as gerações.

Assim, no Brasil, reportagens falam, ao lado da ambição econômica e da tecnicalidade do grupo, da aversão à ingestão de bebidas alcoólicas e de um modo de vida mais "saudável e natural" por parte dos membros mais visíveis da nova geração, além da entronização do seu ídolo, Armínio Fraga, ex-presidente do Banco Central e ex-gestor de fundos de George Soros, agora proprietário da empresa brasileira de intermediação mais requisitada (Dávila, 2004; D'Ambrosio e Vieira, 2004).

Tudo indica que estamos diante da emergência de um novo grupo das elites tanto econômicas quanto culturais, que poderíamos batizar de "patriciado meritocrático fernandista", do qual Fraga é a figura exemplar (Dias, 2000). O reconhecimento da nova nobreza, que nos indica inclusive as novas regras do bem viver, pode ser constatado de diversas formas, como a publicação (e, portanto, a importância) de 
suas opiniões a respeito de assuntos distantes da sua competência profissional reconhecida, como os esportes e as práticas culturais e gastronômicas que devemos considerar de bom-tom. Evidentemente, ele é bem-nascido - patrício no sentido romano -, mas se fez por si só, em um métier distante do praticado pelo seu pai, médico. Ele não é um arrivista irresponsável, saído não se sabe de onde, como recentemente ficou registrada a figura do "simples especulador" Naji Nahas. Apesar das inúmeras tentativas de colar em Fraga o rótulo de especulador, a associação não parece ter sido bem-sucedida. Ele provou sua competência escolarmente, no mundo internacional das finanças e também na posição delicada de presidente do Banco Central que teve como missão administrar a moeda no período em que o país tentava sair da crise cambial deflagrada pelos gestores que o antecederam no BC; $\log$, está coberto de méritos ${ }^{22}$. E é "fernandista" porque a última oitava legitimou o novo padrão de intermediação, possivelmente pela sua caução internacional e sua funcionalidade para a política de privatização das companhias estatais que visava "enterrar o passado corporativo getulista" - um objetivo ao mesmo tempo econômico, cultural e moral.

A categorização positivada de nosso personagem ganha substância se a referenciamos em um espaço social mais amplo. De um lado, contra os banqueiros e financistas tradicionais; de outro, contra o mundo "antifinanceiro". Mais "arejado" do que os banqueiros tradicionais, que costumam cultivar, pelo menos em público, uma imagem conservadora e austera, ele certamente fará uso de sua abertura para o mundo na busca de aplicações mais inteligentes para os recursos dos investidores que o procurarem. Administrador responsável, como provou na gestão do Banco Central, ele não pode ser chamado de aventureiro por aqueles que nutrem desconfianças contra o mundo das finanças, ainda que essa tentativa reapareça continuamente ${ }^{23}$. Em suma, estamos diante de uma receita de como deve ser um bem-sucedido "homem moderno", com toda a conotação positiva que o termo recebe na sociedade brasileira. E aqueles que opõem suas opiniões ou modos de vida ao nosso moderno recebem inapelavelmente o rótulo de "não-modernos", tornando sumamente custoso o confronto direto com o padrão apresentado.

Mas o que mais importa nesse conflito e sucessão geracional é que, por intermédio da economia financeira, a nova geração redefine a idéia de interesse geral que tradicionalmente é cultivada pelo mundo 


\section{Roberto Grün}

das finanças e transporta esse novo critério para a sociedade. Antes os banqueiros queriam ser legítimos porque se apresentavam como o elo entre os possuidores de recursos e aqueles que poderiam fazer bom uso dos capitais na produção de riquezas, criando assim um ciclo virtuoso de aceleração da atividade econômica, com benefícios para toda a nação e, principalmente, sem propor uma esfera de virtude afastada do mundo industrial. $\mathrm{O}$ instrumento por excelência da ação bancária era o desconto de duplicatas - os títulos comerciais gerados por operações de crédito -, e quando os bancos passaram a concentrar-se na negociação de títulos governamentais, não por acaso seus porta-vozes sempre que podiam declaravam que aquela situação era anômala e que suas instituições, assim que pudessem, deveriam abandonar essa atividade, que lembra os usurários medievais, e voltar ao seu papel tradicional, e o único verdadeiramente saudável, de financiadores da atividade empresarial (Troster, 2004).

Agora, no espírito da economia financeira, está sendo propagada uma nova idéia sobre o fundamento da utilidade das finanças para o interesse geral. Elas são absolutamente necessárias para a sociedade, uma vez que só por intermédio delas somos capazes de manter uma vigilância eficiente sobre os atores econômicos, principalmente empresas e países, obrigando-os a adotar o comportamento racional. Essa vigilância se exerce por meio do recurso sistemático à "arbitragem" - a capacidade de os mercados financeiros perceberem o comportamento anômalo de qualquer agente (uma empresa que usa mal seu potencial, um governo que mantém sua moeda "artificialmente" valorizada ou desvalorizada ou mantém um regime inflacionário) - e punir esse ator irresponsável, atacando-o (Mackenzie, 2003). Por exemplo, preparando uma oferta hostil de compra, o take-over, sobre a empresa em questão ou um ataque à moeda do país "malgovernado". Dessa maneira, a vigilância do mercado é vista como o principal instrumento que a sociedade tem para se manter eficiente. E, magicamente, os interesses financeiros privados dos operadores, que podem receber fortunas pelos atos de arbitragem realizados nos mercados, acabam se tornando uma virtude pública. Um corolário importante dessa visão é que governos ou marcos institucionais que protegem as empresas contra ataques na bolsa de valores ou qualquer outra ação financeira, ou mesmo que protegem outros governos na esfera dos organismos multilaterais ou diretamente, longe de estarem sendo virtuosos, na verdade, estão conspirando contra o uso eficiente dos re- 
cursos disponíveis na sociedade e assim contra a nação como um todo, além de, evidentemente, interferirem no fundo de comércio dos novos agentes.

Note-se que, nessa versão recente da economia financeira que tem na arbitragem sua idéia-chave, a racionalidade não é mais um pressuposto do comportamento dos agentes, como na versão tradicional da teoria neoclássica, mas uma performance, produzida pela virtuosidade dos mercados. Esse desenvolvimento corrige a fraqueza congênita da capacidade explicativa do modelo anterior, produzindo uma simulação do comportamento dos agentes muito mais sofisticada. Primeiro, porque a nova versão é dotada de interatividade - a racionalidade torna-se uma característica social, adquirida pelo aprendizado, tanto escolar quanto prático. Segundo, pela sua analogia mais forte com alguns princípios do convívio democrático, como o nosso voto obrigatório: da mesma forma que o brasileiro aprenderia a votar votando, ele tornar-se-ia um investidor capacitado operando no mercado.

Agora, os indivíduos não são simplesmente dotados de racionalidade econômica porque essa seria uma capacidade genética do ser humano, mas chegam a ela tangidos pela força da necessidade de corrigir os resultados dos seus comportamentos passados. A lógica interna dos enunciados ganha muita robustez, e, tendencialmente, o próprio conteúdo típico da profissão de economista muda seus contornos. A busca de oportunidades para realizar arbitragem torna-se o centro da atividade. Nesse quadro, as preocupações com a macroeconomia deixam de ser relevantes nelas mesmas e ganham importância nas suas conseqüências para a administração dos portfolios financeiros. A se julgar pela distribuição recente dos prêmios Nobel de economia, a caução intelectual para esse desenvolvimento recente também se revela fortíssima (Lebaron, 2000). Então, a não ser que mudem os eixos culturais pelos quais se travam as discussões econômicas atuais, nunca estivemos diante de uma versão da teoria econômica que ancorasse tão legitimamente o darwinismo social, com a possível exceção dos usos da teoria econômica de inspiração malthusiana no Colonial Office inglês do século XIX, cuja análise pode servir para melhor entendermos esse efeito cultural da teoria econômica (Thompson, 1993; Lebaron, 2003). 


\section{Roberto Grün}

Estamos diante de uma sólida construção cultural, que explica e ordena o mundo em que vivemos, fornecendo explicações lógicas para nossas vicissitudes pessoais e coletivas. Sua força e sua fraqueza podem ser atestadas a partir do enquadramento que faz dos problemas econômicos que consideramos mais prementes. Assim, a persistência do desemprego, aparentemente uma prova da ineficiência da visão financeira para dirigir nossos destinos, não é verdadeiramente um problema econômico. Ele existe porque o sistema político, uma esfera que ainda está longe de alcançar uma boa governança, se revela incapaz de tomar as medidas corretas no sentido de eliminar os entraves que permitam a livre arbitragem do mercado. $\mathrm{O}$ vilão a exorcizar é, portanto, a legislação trabalhista que, sob a aparência de proteger os trabalhadores, os condena a viver com uma procura medíocre para suas habilidades atuais e com fracos incentivos para dotarem-se de novos atributos que possam ser apreciados. Individualmente, os exemplos de sucesso, como o de Fraga, são o "mapa da mina". Perseguir o exemplo ou não fazê-lo é uma decisão individual, deixada ao livre-arbítrio de cada um de nós. Mas o custo por afastar-se do caminho "real" é imputado ao indivíduo. A culpa de um eventual fracasso é dele e não da sociedade, inclusive porque a nossa "pós-modernidade" nos dotou de uma panóplia de instrumentos para reconstruirmos nossas trajetórias pessoais e profissionais (Grün, 2003b).

Assim, a visão de mundo construída em torno da idéia de arbitragem, que apóia a entronização do novo grupo no seio das elites brasileiras, parece difícil de se combater. Parafraseando Goodman (1988), ela constrói um mundo completo e, por isso, muitas vezes robusto ${ }^{24}$. Caminhando no halo da apropriação sociológica do tema indicada por Bourdieu (1997:221-222), a luta para influenciar a maneira como a sociedade pondera o valor de cada evidência na construção das versões prevalecentes de como devemos entender o mundo que nos cerca é a essência mesma da luta política - a luta que produz as categorias cognitivas que informam a nossa percepção do mundo social e assim conferem justiça, familiaridade ou estranheza aos eventos com que nos deparamos. No quadro dessa guerra cultural que estamos descrevendo, a maneira como a sociedade encara o desemprego - como um problema surgido da economia ou da política -, ou se ela aceita a teodicéia proposta pela nova elite, concordando com a existência de dons naturais que conferem legitimidade às pretensões do grupo, ou ainda se, ao contrário, a sociedade considera que estamos simplesmente di- 
ante de mais um grupo de aproveitadores privilegiados, tornam-se bons reveladores fotográficos da robustez do worldmaking.

\section{As poucas alternativas dos inimigos das finanças}

A legitimidade desse novo grupo e da visão financeira como norteadora das escolhas sociais teria se esvaído com a derrota eleitoral na eleição presidencial de 2002 do candidato ligado a Fernando Henrique? Responder um "sim" inequívoco a essa pergunta é uma vanidade fácil de se acalentar, ainda que drasticamente desmentida pelos fatos, pelo menos até um ano depois da posse de Lula. Mas, muito além de ser um equívoco freqüente, também é uma interessante questão de sociologia que merece uma explicação analítica. Creio, em bon Bourdieu, que a resposta sociológica repousa sobre a exploração de uma homologia (Bourdieu, 1984) entre as posições que os petistas ocupavam na esfera restrita das elites políticas no período em que estiveram na oposição e diversos setores "antifinanceiros" na esfera da sociedade em geral.

No período fernandista, diversos quadros ligados ao PT e à CUT tentaram reerguer a idéia das câmaras setoriais que surgiram com força durante o governo Itamar Franco (Anderson, 1999). Em um momento em que o Consenso de Washington se impunha como o único caminho possível para as economias latino-americanas, as câmaras tornaram-se a resposta petista prática ${ }^{25}$ aos problemas do desemprego e do desenvolvimento econômico. De um lado, no ambiente recessivo produzido pelas políticas de austeridade monetária, as mobilizações setoriais que elas deflagravam permitiam ganhos para setores representados pela CUT, talvez mais precisamente uma diminuição de perdas; de outro, sua visibilidade produzia ganhos políticos que demonstravam que a oposição não estava morta: ela tinha uma alternativa concreta ao Consenso ${ }^{26}$. Reparemos: uma alternativa adequada ao espaço de representatividade que seus quadros ocupavam naquele momento. Os sindicalistas e ex-sindicalistas deixavam de simplesmente dizer "não" e passavam a unir interesses até então vistos como antagônicos, mostrando-se assim atores institucionais responsáveis, e incontornáveis. Por sua vez, os prefeitos das cidades industriais administradas pelo PT e aliados também encontravam uma resposta, pelo menos retórica, aos reclamos dos seus eleitores, que afinal eram os mais diretamente atingidos pelas transformações econômicas, e estavam muito mais próximos deles do que de Brasília. Além disso, 


\section{Roberto Grün}

subsidiariamente, a abordagem das câmaras setoriais também contribuía para caracterizar o desemprego como um problema econômico, produzido pela política de austeridade monetária, pela insensibilidade diante dos problemas da indústria, e não um problema político produzido por um marco institucional anacrônico. Assim, se no período considerado as câmaras não prosperaram na sua finalidade oficial, nem por isso deixaram de ser relevantes nas estratégias diretas daqueles que as empreenderam.

A homologia acontece por causa do princípio que rege a idéia de câmara setorial - o da coordenação, sistematicamente procurada, da ação dos diversos agentes envolvidos por meio da criação de um consenso, seguido do planejamento de ações conjuntas. Este princípio se opõe cognitivamente à idéia de coordenação "espontânea" dos agentes econômicos por via da força imposta pela concorrência no mercado livre, auto-regulado (Grün, 1999). Ele repõe na arena a idéia de planejamento do desenvolvimento como centro da atividade econômica governamental, em contraposição à idéia quase consensual nos últimos anos de que o centro dessa atividade deve ser a criação e manutenção de condições institucionais e macroeconômicas favoráveis à atração de investimentos privados. As ações econômicas e políticas baseadas na coordenação sistemática também servem como uma espécie de blue-print para a busca de soluções, pelo menos retóricas, para os problemas macroeconômicos com que se deparam as lideranças sindicais. Um exemplo recente foi a ação conjunta do sindicato de trabalhadores, da empresa e do poder local na remodelação da fábrica da Volkswagen da Via Anchieta ${ }^{27}$. Esta iniciativa acabou se tornando uma verdadeira declaração dos princípios que norteiam a visão de economia inspirada pela argumentação industrial e realçou o vínculo que parece unir os membros da direção do PT com esse princípio ${ }^{28}$.

\section{Das mordomias ao problema da média gerência}

Alvo de ataques que começaram com a série de reportagens sobre as "mordomias do setor estatal" publicadas pelo jornal O Estado de $S$. Paulo a partir de agosto de 1976 (Kotcho, 1976), o mundo das organizações, na sua totalidade, sente-se de alguma maneira representado por aqueles que parecem estar empunhando na esfera da política o princípio da coordenação sistemática. É importante notar que, se o ataque inicial visava o setor estatal "hipertrofiado pelo gigantismo dos militares", ele claramente não se deteve no primeiro alvo, miran- 
do em seguida o espaço das organizações privadas, brandindo a bandeira da produção enxuta e a da organização sem gorduras. No espaço cultural que se apresentava no período, a única defesa eficiente contra aquela ofensiva foi a idéia de qualidade total, que apareceu na década de 80, e não é por acaso que ela se propagou rapidamente em espaços organizacionais tão diversificados. Mas a qualidade, além de se situar claramente como um compromisso entre as duas lógicas econômicas ${ }^{29}$, funcionou no período como uma arma para os gerentes profissionais manterem e, eventualmente, recuperarem o controle social dos espaços organizacionais em disputa com o poder sindical, além de se defenderem da acusação de serem burocratas análogos aos funcionários públicos. Dessa maneira, sua possível utilidade para unir o mundo industrial contra os inimigos comuns não foi percebida, perdendo vez para a focalização dos agentes na disputa dentro das organizações ${ }^{30}$. Ademais, qualquer que tenha sido o resultado dessa luta interna, a partir de meados dos anos 90 o espaço de liberdade no mundo organizacional diminuiu drasticamente e os compromissos foram se tornando cada vez mais difíceis, preponderando a idéia do enxugamento, propagandeada pela "reengenharia" - o braço micro das pressões financeiras -, sobre a idéia da mobilização das capacidades intelectuais e produtivas de todos os membros das organizações, que representava o grande trunfo social da idéia da qualidade $^{31}$.

A reengenharia produzia uma pressão enorme sobre a vida organizacional. Mas ela era localizada no tempo, sendo normalmente realizada por meio de consultorias de duração limitada. Mais recentemente, começou a ser secundada por uma série de instrumentos de gestão de uso contínuo, inspirados na mesma idéia, vinda da economia financeira e da agency theory, de que a empresa deve ser vista como um feixe de contratos entre indivíduos bem definidos no tempo, no espaço e em abrangência. Essas "ferramentas" apresentam um crescendo de controle e individualização da medida do desempenho, operando, na esfera cognitiva, como instrumentos importantes na tentativa de fazer desaparecer a "velha" idéia de trabalho coletivo e, nas suas visões mais extremas, a própria idéia de empresa.

A primeira ferramenta que adquiriu popularidade no mundo organizacional foi o chamado "custeio $A B C$ ", que propunha a mensuração completamente isolada da realização de lucro ou de despesas de cada unidade da organização. Essa finalidade seria alcançada pela aboli- 


\section{Roberto Grün}

ção da diferença entre custos fixos e custos variáveis (Armstrong, 2002; Colwyn Jones e Dugdale, 2002). No esquema de custeio tradicional, os custos fixos (instalações, mão-de-obra indireta e de supervisão etc.) eram de toda a empresa, deveriam ser rateados pelos seus diversos departamentos e constituíam-se na base contábil para a idéia mesma de empresa indissolúvel. Dessa forma, apenas os custos variáveis (matérias-primas, mão-de-obra direta etc.) deveriam ser imputados a cada linha de fabricação de produtos. A finalidade organizacional da tentativa de dissociação era clara: acabar com as ambigüidades na avaliação do desempenho das empresas que impediam a completa divisão das suas atividades-meio entre as múltiplas linhas de produtos ou serviços. As conseqüências sociológicas dessa individualização dos diversos setores das organizações logo começaram a se fazer sentir. O novo instrumento permitia que, tanto contabilmente quanto cognitivamente, a empresa pudesse ser vista como um conjunto de unidades independentes, apenas provisoriamente trabalhando em conjunto, em suma, anunciando a idéia de organização pensada como o feixe de contratos da agency theory. Rapidamente, a perseguição desse modelo, até então exótico, se torna uma necessidade, provida de um roteiro claro, para alcançar a "excelência". Em uma primeira fase, a "ferramenta" foi apresentada sozinha; mais recentemente, como um sinal da sua maturidade e naturalização dos princípios que a inspiraram, ela passou a fazer parte dos grandes sistemas informáticos de gestão organizacional integrada chamados de ERPs (Enterprise Resource Planning), considerados de utilização praticamente obrigatória nas empresas modernas (Colwyn Jones e Dugdale, 2002). A enorme difusão desses novos instrumentos consagrou a técnica contábil e espalhou sua influência cognitiva por horizontes cada vez mais amplos, bem além do ambiente das organizações industriais para as quais eles foram concebidos.

Em seguida ao custeio $\mathrm{ABC}$, temos uma bifurcação dos instrumentos, que corresponde, grosso modo, a uma diferenciação de perspectivas que sinaliza uma nova polarização do espaço empresarial, agora interna à preponderância da argumentação financeira. De um lado, aparece o chamado Balanced ScoreCard - BSC (Kaplan e Norton, 1996), proposto pelo mesmo grupo responsável pela "ferramenta" anterior; do outro, o Economic Value Added -EVA (Lordon, 2000b). O BSC, no espírito de Porter (1985), que propõe a descoberta e manutenção de aspectos positivos decisivos de cada empresa - no jargão, as suas vanta- 
gens competitivas -, pretende ser uma interface organizando a ligação entre os aspectos não financeiros da empresa e aqueles diretamente financeiros. Já no EVA, a pretensão é efetuar uma medição direta, contínua e sistemática da lucratividade diferencial (i.e, além das taxas médias ou esperadas) de cada unidade e mesmo de cada indivíduo engajado na empresa que deverá servir como base central para qualquer tomada de decisão, em especial as de investimento e de venda de ativos, além da remuneração e dispensa de funcionários.

A avaliação crítica de cada uma das ferramentas levanta dúvidas quanto à efetividade das promessas anunciadas e também sobre seus efeitos precisos na realidade empresarial. $O$ custeio $A B C$ não conseguiria realmente individualizar e redefinir as estruturas de custos de maneira a imputá-los inequivocamente a cada fonte de lucro (Armstrong, 2002). O BSC não conseguiria fazer a junção entre aspectos financeiros das empresas, como lucro e liquidez, e aqueles não financeiros, como produtividade, qualidade e capacidade de inovar (Norreklit, 2000). Por sua vez, bons resultados na métrica do EVA também não garantiriam resultados financeiros excepcionais, que seriam medidos pela valorização dos preços das ações e lucratividade, à empresa que os alcance (Froud et alii, 2000). Entretanto, qualquer que seja a relação entre os resultados prometidos pelas técnicas e as transformações efetivas que a sua adoção poderia produzir, restam seus potentes efeitos retóricos (Norreklit, 2003). Na verdade, eles anunciam, sem ambigüidades, que a "antiga" empresa hierárquica, previsível, lócus fundamental da sociabilidade de seus integrantes, está irremediavelmente fora do caminho da evolução da sociedade. No nível individual, realça a idéia de que devemos nos preparar para outras realidades, nas quais os velhos anteparos coletivos não mais funcionarão, devendo ser substituídos por esquemas individualizados de segurança financeira, profissionais, de saúde e mesmo emocionais.

Podemos assim, a partir da análise do que se passa nos ambientes de trabalho modernos, dizer que o mundo organizacional hierárquico, que engloba os espaços empresarial e estatal, lócus de inumeráveis estratégias profissionais e de carreira, está sob fogo cerrado. As atitudes do PT no espaço político antes das eleições de 2002 conotavam a intenção de defender esse mundo ameaçado. Lembremos que o espaço dos prejudicados é bem amplo. O mundo econômico proposto pelas finanças rejeita uma série de prejulgados que dão base não só à estrutura das empresas, mas também à das profissões, como o primado 


\section{Roberto Grün}

da antiguidade na aferição do mérito, como o papel fundamental dos títulos escolares na medida da qualificação das pessoas, e outros.

Outra fonte importante para a criação do efeito homológico foi a atitude compassiva do candidato Lula em relação à questão social ${ }^{32}$. A necessidade de registrar e reiterar o cuidado com os menos aquinhoados é ponto essencial da seqüência mnemônica deflagrada pelo pensamento hierárquico, que fornece a base cognitiva para o entendimento tradicional de como devem funcionar e o que devemos esperar das organizações (Douglas, 1996) ${ }^{33}$. Independentemente de sua efetividade, a insistência nas idéias propagadas pelo Programa Fome Zero e outras formas de assistência social continuam reiterando a sensação de familiaridade do atual governo com a família de pensamento. No espaço cognitivo deflagrado pelas idéias financeiras, a atitude, também aqui não importando a distância entre discurso e prática efetiva das políticas que são decorrentes dessa maneira de pensar, o espírito é outro: trata-se de assegurar a lisura e a igualdade básica de chances na competição social (Boltanski e Thévenot, 1991).

Em suma, estamos diante de alguns setores da sociedade brasileira altamente predispostos a aceitar a pregação petista, e através de um filtro cognitivo bem claro. Sobre a efetividade dos filtros, é interessante notar alguns aspectos da campanha eleitoral de 2002. No programa de Lula, as câmaras setoriais a pareciam bem-acanhadas, e no capítulo de política social, em vez daquele de política econômica, denotando a sua perda de importância ${ }^{34}$. Por outro lado, os feitos que poderiam ser computados como decorrentes delas estavam sendo catalogados como provas da capacidade política dos prefeitos petistas das regiões afetadas pelas políticas setoriais. Mas, talvez por falta de alternativas, nenhuma dessas possíveis evidências ganhava o status de "contraprova" que diminuísse o caráter do Lula-contra-tudo-que-está-aí, em especial contra o poder das finanças e contra o novo mundo que elas estão desenhando. Por outro lado, no plano da escolha de táticas eleitorais eficientes e além do que se passava internamente ao PT, outras evidências da campanha de 2002 mostravam que o caminho da antifinanceirização está interditado para as candidaturas que pretendam vencer eleições e chegar ao poder. Na tentativa de alijar Serra do segundo lugar e forçar um segundo turno contra Lula, tanto Ciro Gomes (Seabra, 2002) quanto Anthony Garotinho (Folha de S. Paulo, 2002) tentaram usar essa carta e só conseguiram ser considerados candidatos "destituídos de seriedade" pelo conjunto da imprensa e, apa- 
rentemente, pelos formadores de opinião, sepultando de vez suas pretensões $^{35}$. Na campanha de Ciro Gomes (Felício, 2002), a carta foi jogada mais consistentemente e pudemos ver que ela levava a um caminho incômodo: a toada antiplutocracia rapidamente começou a evocar a velha música do regionalismo antipaulista e foi tachada de fascistizante ${ }^{36}$.

Talvez porque os prejudicados pela financeirização fossem uma espécie de clientela cativa do PT, fidelizada pela ação simbólica do partido em momentos anteriores, talvez simplesmente por falta de resistência, talvez ainda porque a retórica antifinanceira não é bem recebida na sociedade brasileira em geral, eis que, enquanto seus possíveis adversários atacavam os bancos, Lula e o seu séqüito aproximavam-se de diversos atores do mundo financeiro - o episódio da ida de Lula à Bolsa de Valores de São Paulo - Bovespa sendo o evento mais marcante (Murphy, 2002). A aproximação foi completa e sem ambigüidades? Pelo que vimos acima sobre a diferenciação do espaço das finanças, é claro que não. A Bolsa de Valores representava um dos setores menos privilegiados daquele campo, o espaço dos corretores locais - na linguagem de Bourdieu, o pólo dominado. Além da Bolsa, havia os fundos de pensão, também atores dominados no jogo financeiro do período fernandista, e no seio dos quais os petistas já estavam implantados. A ida de Lula à Bolsa reforçava os laços entre as duas ordens de atores e a posição dos petistas na disputa pelo comando dos fundos. Assim, estava formada a confluência que produziu a homologia - o pólo dominado do campo político encontrava-se com o pólo dominado do campo financeiro, uma situação interessante para ambos os grupos. O espaço social possibilitava uma entrada relevante no mundo econômico para os petistas, que necessitavam de caução para suas pretensões ao governo central, e uma entrada no mundo político para os setores econômicos, que precisavam desse apoio para tentar renegociar seus posicionamentos diante do pólo dominante do seu campo.

No espaço dos atores que se ocupam da representação de seus pares, a situação parece confortável para todos, mas no espaço social, como nos advertia constantemente Bourdieu, estamos diante da possibilidade de um trompe-l' l' $^{\prime}$ il generalizado. Os interesses que são específicos e contingentes para os grupos políticos nas disputas por espaços no seu campo são interesses críticos, fundamentais para a sobrevivência dos grupos sociais que se sentem representados pelos princípios que a atuação pregressa do PT sugeriu que o partido fosse empu- 


\section{Roberto Grün}

nhar uma vez no poder. Se o campo político mantiver a sua autonomia, controlando a pressão dos eleitores e grupos de interesse, a distância entre o padrão de atuação sugerido pela história do partido e a ação governamental tende a aumentar. Nesse espaço, salvo a ocorrência de perturbações externas que produzam heteronomia no campo, a idéia de arbitragem é fundamental. Disputa-se o troféu que ela instituiu, o da melhor gestão do cotidiano econômico, aferida pelo teor e repercussão imediata das notícias no mundo financeiro, principalmente pelos seus reflexos nas bolsas de valores, nas taxas de câmbio e nos preços dos títulos externos brasileiros. Enfim, uma agenda definida pela ameaça da espada de Dâmocles que a arbitragem impôs às sociedades. Se estas não agissem de acordo com as recomendações, a ação dos mercados financeiros rapidamente se faria sentir: teríamos ataques contra a moeda e demais haveres do país que ousasse desafiar as leis da ortodoxia econômica. Nessa disputa pelo centro do tabuleiro político, o melhor governo seria justamente aquele que melhor nos defendesse contra os mercados, sempre de acordo com a opinião padronizada sobre o comportamento daquelas instituições ${ }^{37}$.

O atual governo parece procurar a coerência com as expectativas geradas antes das eleições, declarando a dissociação das chamadas políticas microeconômicas do Estado das ações macroeconômicas, marcadas pela ortodoxia financeira ${ }^{38}$. Talvez a principal ação visível no primeiro ano do governo Lula em prol do princípio da coordenação procurada tenha sido a adoção do conceito de "concertação" ${ }^{39}$ pelo Conselho de Desenvolvimento Econômico e Social criado sob a direção do ministro Tarso Genro, que produziu um incômodo visível nos comentaristas mais comprometidos com a visão financeira da economia (Folha de S. Paulo, 2003). O progressivo esmaecimento tanto do uso do conceito quanto da atuação do Conselho, ou, ao contrário, seu eventual ressurgimento, podem ser considerados indicadores da potencialidade desse gênero de ação simbólica e econômica destoante dos princípios que regem a ação econômica e política (até agora?) relevante do atual governo.

Outra iniciativa, cognitivamente baseada na aplicação do mesmo princípio, é o apoio aos chamados Arranjos Produtivos Locais APLs, que se constituiriam em um instrumento direto de ação "microeconômica" do governo federal ${ }^{40}$. A ancoragem é forte: nos APLs o governo federal reencontra parceiros que funcionam ou justificam o seu funcionamento no fomento da ordem industrial, como a Federa- 
ção das Indústrias do Estado de São Paulo - FIESP, o Serviço Brasileiro de Apoio às Micro e Pequenas Empresas - SEBRAE, atores locais e, eventualmente, sindicatos e cooperativas de trabalhadores ${ }^{41}$. Mas essas ações locais dificilmente seriam capazes de roubar a atenção que as ações macroeconômicas recebem normalmente e, assim, inverter a apreciação geral de que o atual governo federal preferiu o rumo da ortodoxia econômica, o atendimento dos reclamos da galáxia financeira, às necessidades dos membros e apoiadores da comunidade industrial. Não é, evidentemente, descartada a descoberta ou invenção de casos de êxito estrepitoso de algum tipo de aglomeração fomentada, do gênero dos APLs. Poderíamos imaginar um, ou vários clusters, cuja atividade produza impacto sobre as contas externas, mostrando um caminho generalizável para exportações de alto valor agregado ou para a substituição de importações que produzam efeito equivalente. Uma situação dessas produziria forte efeito-demonstração e parece estar no mapa das tentativas dos governistas, em particular nos ramos considerados de ponta, como os softwares ou a biotecnologia.

É interessante notar que, na oitava passada, no halo da bolha da alta tecnologia, os fundos de pensão ensaiaram a entrada em atividades de capital de risco, no que foram impedidos pelas autoridades federais. No atual momento, o foco com que o governo pretende conduzir os fundos está nas PPPs. A bolha da alta tecnologia estourou nos EUA, mas nada impede que os fundos voltem a interessar-se pelo fomento a atividades nascentes como as da alta tecnologia, ou que sejam direcionados a elas. Nesse caso, estaríamos diante de uma ampliação da atividade "microeconômica" induzida pelo governo federal, restando saber se ela seria considerada adequada pelos "árbitros" do mercado. Afinal, a sabedoria convencional dos mercados (Galbraith, 1998) sempre pode considerar qualquer atividade "subótima" e influenciar as autoridades fiscalizadoras, os pensionistas e os rivais dos petistas na sua representação, no sentido de inviabilizar as aplicações de risco, nos PPPs ou quaisquer outras que estiverem no horizonte.

\section{CONCLUSÃO}

O nome da entidade é arbitragem. Uns consideram-na santa e a invocam com prazer, outros vêem nela um demônio a ser exorcizado com temor. Mas todos admitem a sua existência. Uns pavimentando o caminho para que os novos instrumentos financeiros e seus arautos se desenvolvam no país, outros preparando defesas contra, tentando di- 


\section{Roberto Grün}

minuir a exposição internacional por meio da diminuição e alongamento da dívida pública. Em ambos os casos, subordinando as demais necessidades nacionais ao império da arbitragem. Poderíamos analisá-la pelo seu lado de artefato econômico, comprovando os seus efeitos ou refutando as evidências em nome de outra explicação. Mas ela é também um artefato cultural, dotado de uma solidez que pouco se abala diante das impugnações científicas.

A força das novas finanças, e da arbitragem em especial, repousa em bases mais sólidas do que a sua robustez econômica. Estruturalmente, elas são construções culturais baseadas na mesma estrutura metafórica que funda a sociedade capitalista. Seus instrumentos são virtuosos porque contribuem para manter a auto-regulação tanto do mercado quanto da sociedade como um todo. Douglas e Ney mostram os passos da solidificação da metáfora do mercado auto-regulado como essência da vida social. Ela é baseada na analogia entre a noção dos rendimentos decrescentes na natureza e na economia, passando pela idéia de apetites auto-regulados na esfera da psicologia. Assim como devemos ser sábios, retirando da natureza apenas o que ela pode recuperar e repor, devemos igualmente moderar nosso apetite em sociedade, pois, se não o fizermos, seremos irremediavelmente punidos (1998:33-36). E os instrumentos que tornam a punição mais rápida são virtuosos, porque ajudam a sociedade a restabelecer o equilíbrio mais rapidamente e com menores danos.

Conjunturalmente, vimos o ganho de legitimidade dos agentes sociais que fazem dos novos procedimentos financeiros o seu fundo de comércio. A comparação esboçada entre o "patrício" Armínio Fraga e o "arrivista" Naji Nahas parece-me um bom instrumento para essa medida ${ }^{42}$. Enquanto o primeiro continua gozando de excelente trânsito nos circuitos das elites brasileiras e na imprensa, o segundo, sempre que ensaia uma reaparição, mesmo quando aparentemente em prol de uma causa respeitável, é rapidamente estigmatizado ${ }^{43}$. Temos assim uma esfera das finanças legítima e outra ilegítima - e nunca é demais lembrar o esforço inglório, não só nas margens da esfera política, mas também no seu centro, no sentido de tentar caracterizar o ex-gerente de fundos de George Soros (que por sua vez também muda de roupagem, investindo na identidade de filantropo e de filósofo social) e seu grupo como especuladores do mesmo naipe que Nahas, ou aventureiros dogmáticos como Gustavo Franco. 
A outra diferenciação que propus é a que divide o mundo das finanças entre atores nacionais, dominados, e atores internacionalizados, dominantes. Aqui, temos de nos acautelar contra a ilusão homológica. Os grupos que deram guarida a Lula e seu séqüito apenas tentavam melhorar seus posicionamentos no campo financeiro e não uma reformulação drástica daquele espaço. Talvez a conexão surgida em 2002 tenha evitado uma propagação ainda mais rápida da impugnação que os mercados financeiros internacionais decretaram contra o PT, diminuindo os estragos da corrida contra o Real. Mas o comportamento dos atores após a posse do novo presidente da República não deixa margem à dúvida. A hierarquia do espaço financeiro continua a ser respeitada, ainda que o novo governo aqui também tenha ensaiado passos diferentes, como na tentativa de sedução tentada junto aos fundos de pensão internacionais em maio de 2003, buscando novas fontes de investimento no país, possivelmente distintas daquelas operadas pelos "árbitros" (Batista, 2003).

A força dos constrangimentos estruturais aparece justamente por meio da não-continuidade das tentativas de sair do script restrito do mundo da arbitragem. Não é a falta de opções que nos conduz ao caminho da ortodoxia financeira. É a defesa prévia contra o peso avassalador das possíveis impugnações que os árbitros poderiam proferir. Ela acaba construindo a agenda dos possíveis e da ação governamental e, subordinando as possíveis alternativas às suas premências, termina por descartá-las.

O espaço para os grupos que foram diretamente atingidos pela financeirização se restringiu mais ainda no primeiro ano do novo governo. Aqui, a mensagem é clara. Fala-se de uma reforma trabalhista distinta da reforma sindical. Aceita-se, pelo menos em parte, o argumento de que o emprego não cresce por causa do marco regulatório restritivo (Rolli e Fernandes, 2004). Logo, os contratos de trabalho formais devem ser flexibilizados e com eles as estruturas formais das organizações. Consubstanciando esse entendimento, a ação em prol dos APLs, normalmente aglomerados de pequenos empreendimentos ainda no nascedouro, dificilmente poderia redundar em elevação do emprego formal. As atividades fomentadas pelos fundos de pensão, uma das alavancas do desenvolvimento, tampouco tendem para o coração da área industrial, onde costumam ser produzidos os empregos tradicionais - formais, com expectativa de carreira e estabilidade. Pelo contrário, até o momento, os investimentos dos fundos têm fomentado 


\section{Roberto Grün}

mais as atividades de serviços, como os shopping centers e o turismo, criadoras típicas de empregos temporários e informais, e em muito menor escala empreendimentos industriais, como a Empresa Brasileira de Aeronáutica - EMBRAER, que tendem a manter uma maior proporção de empregos formais e com perspectivas de carreira.

De maneira geral, o grande desafio para os inimigos da ordem financeira é montar uma agenda que não seja taxada de particularista ou de corporativa. Vimos a proximidade freqüente entre essas idéias e posturas extremistas, normalmente catalogadas como de extrema-direita. Há certamente uma lógica mnemônica que produz a convergência. Ela é inevitável? Provavelmente não, mas os diversos casos, históricos ou recentes, nacionais ou internacionais, ocidentais ou orientais, mostram que as probabilidades jogam pela junção. Nesse sentido, seria interessante acompanhar o desfecho da estratégia de desafio ao FMI que o governo Kirchner está empreendendo na Argentina. Uma negociação argentina, que receba o enquadramento de "bem-sucedida" 44 na agenda brasileira, poderia deflagrar pressões fortes contra a atual condução da economia, rearticulando as vozes caladas pelo início do governo Lula.

Um outro desfecho possível vem da possibilidade de uma degringolada interna do mundo financeiro. A história das finanças (Mackenzie, 2003) mostra que as agendas políticas de períodos bafejados por crises financeiras tendem a restringir drasticamente a abrangência da expansão possível dos produtos desenhados para aumentar a liquidez do sistema capitalista, chegando mesmo a proibi-los. Notavelmente, não tivemos esse resultado no Brasil recente e talvez até o contrário. Em um período de grita geral contra os altos custos da intermediação bancária, e logo em seguida à vitória do PT nas eleições presidenciais, eis que uma tímida tentativa de manter, ainda que apenas na retórica, o sabidamente ineficiente tabelamento dos juros bancários sofreu uma impugnação tão severa que fez o tema submergir novamente e parece ter contribuído para erradicar do atual governo qualquer veleidade que possa chocar-se com a rota da ortodoxia (Leonel e Tavares, 2003). Assim, a análise do espaço cultural que determina os graus de liberdade e as alternativas diante do mundo financeiro mostra um ambiente extremamente adverso aos setores que pretendem opor-se a ele.

(Recebido para publicação em março de 2004) (Versão definitiva em junho de 2004) 


\section{A Evolução Recente do Espaço Financeiro no Brasil e Alguns Reflexos...}

\section{NOTAS}

1. Bons exemplos, recentes, norte-americanos da primeira corrente são Fligstein (2001) e Abolafia (1996). Uma síntese da visão "bourdieusiana", mais próxima da "construção social dos mercados", mas incorporando alguns pontos da outra corrente, pode ser encontrada em Bourdieu et alii (2003). Dois representantes fortes da segunda corrente são Knorr Cetina e Mackenzie (ver, em especial, Mackenzie, 2002 e Knorr Cetina e Bruegger, 2002a; 2002b).

2. Ver <http://sfs.kellogg.northwestern.edu $>$ e $<$ http://www.siswo.uva.nl/ES $>$.

3. Sobre o significado do conceito de "capital" em Bourdieu, suas coincidências e diferenças com os usos do termo na teoria econômica e os mal-entendidos que ele provoca nos leitores pouco familiarizados com o autor, ver Boyer (2003).

4. Trata-se de um famoso fundo de investimentos, concebido e gerenciado por economistas famosos, de muito sucesso nos anos 90, cuja insolvência causou grande impacto no mercado financeiro internacional.

5. Essa interpretação é só aparentemente análoga à do "efeito manada", a partir da qual a economia tenta dar conta do fenômeno. Para a sociologia das finanças, esse fenômeno do comportamento mimético é permanente, enquanto para os economistas ele só aparece na ordem das explicações quando surgem fenômenos de exceção, não explicáveis por via do quadro analítico tradicional, advindo da hipótese da racionalidade dos agentes econômicos.

6. Nesse quadro analítico, o grande pecado do governo Clinton teria sido a sua política de diminuição da dívida pública, ao contrário daqueles outros que ganharam destaque na imprensa.

7. A assimetria de informações que permite aos gerentes-representantes enganarem seus acionistas-representados é o ponto fulcral da explicação - não exatamente constatado, mas tornado um axioma - do comportamento dos gerentes profissionais das grandes empresas, o qual, nessa chave analítica, deve necessariamente derivar para condutas que prejudiquem os acionistas, já que os indivíduos tendem a maximizar as suas utilidades em detrimento dos direitos alheios, a não ser que sejam coibidos. O desenvolvimento sistemático da idéia está em Fama (1980). Uma crítica sistemática da hipótese e de suas conseqüências, em Perrow (1990). Em um outro registro, em parte ecoando o texto já clássico de Galbraith (1967) sobre o papel da "tecnoestrutura" nas grandes organizações, Lordon (2002) faz uma análise da tendência do capital industrial para a busca de crescimento, a qualquer custo, da escala de operações, para em seguida mostrar que seu contraponto financeiro só retoricamente age no sentido "correto" da acumulação de capitais sem interferência alguma de considerações de status.

8. Evidentemente, os partidários da economia financeira podem fazer acusações simétricas aos sociólogos da mouvance. Eles seriam assim tachados de defensores da "gastança" e da ineficiência burocrática que promove o funcionalismo à custa das populações que deveriam ser bem atendidas e não o são, ou estimuladas a enfrentar de frente seus desajustes para integrar-se orgulhosa e produtivamente à sociedade, em vez de manterem-se como clientela cativa e subordinada aos "esquerdistas do Estado". Sobre a eficiência desse argumento nos anos 80 e início dos 90, ver Handler (1996). 


\section{Roberto Grün}

9. Sobre os mal-entendidos sociais que levaram à produção do "problema", ver Bourdelais (1993).

10. Posteriormente, com a diferenciação cada vez maior das possibilidades de aplicações financeiras que se foram tornando disponíveis no país, a questão tornou-se menos dramática e a "terceirização" avançou com maior rapidez.

11. As PPPs foram postas na cena "da esquerda" pelo New Labour de Blair. Sua aplicação, principalmente na esfera regional ou local, na qual ganham o nome de Private Finance Iniciative - PFI, naquele país produziu muito ceticismo, tanto à esquerda quanto à direita do espectro político (ver, entre outros, Froud, 2003 e Weaver, 2003).

12. Até o final da década de 90 , a maior parte dos analistas críticos era cética em relação às possibilidades de expansão do modelo de governança corporativa norte-americano para países não anglo-saxões. No início do século XXI, as análises passam a constatar a adoção de vários preceitos norte-americanos nos países mais afeitos às regras de convivência "social-democratas", e alguns autores irão falar de convergência dos diversos modelos de capitalismo para o modelo norte-americano (Lane, 2003), enquanto outros preferirão a idéia da hibridização de modelos (Streeck e Yamamura, 2001; Vitols, 2002).

13. Ver detalhes da justificativa e uma discussão sobre como a governança corporativa alcança o estatuto de interesse geral da nação em Grün (2003a).

14. Ver a frase elucidativa no despacho da Agestado de 7/9/2000, às 17h21, intitulado "Fraga: governo incentivará fundos de pensão": "Acredito que o boom de produtividade registrado pela economia dos Estados Unidos tem mais a ver com boa governança do que propriamente investimentos em tecnologia da informação". O anúncio do novo consenso, que substitui a antiga idéia do declínio empresarial norte-americano, que teria sido causado pela melhor performance industrial japonesa e do qual as palavras de Fraga são um eco interessante, é apresentado em The Economist, 15/1/1994, pp. 65-66.

15. Por exemplo, por intermédio das recomendações repetidas da Organização para Cooperação e Desenvolvimento Econômico - OCDE, que promove sistematicamente estudos, seminários e publicações sobre o tema (OECD, 2003).

16. Sobre as flexões de que os discursos econômicos e organizacionais dominantes são objeto diante da prática empresarial e governamental, ver Lordon (2002).

17. Aos bancos pedia-se segurança e solidez, cabendo às instâncias fiscalizatórias do governo federal o controle da sua honestidade.

18. Ver Galvão (2004) e os sites <http:/ / www.acionista.com.br/bovespa/fundos_recebiveis_27_02_04.htm>; <http://www.tvbovespa.com.br/pdf/RevistaCapitalAberto5.pdf $>$. Para uma análise da tendência internacional à diferenciação entre a intermediação oferecida pelos bancos comerciais e aquela proposta pelos novos agentes, ver Aglietta e Orléan (2002).

19. Sobre a pré-história das opções, das acusações contra o seu uso e da tentação de ganho que elas despertam, ver Cardoso (2002), comentando o clássico do século XVII Confusion de Confusiones (Penso de la Vega, 1977).

20. Embora no atual momento a relação entre os novos gestores e os bancos estabelecidos seja provavelmente mais interativa, com bancos constituindo fundos de investimento de gestão terceirizada, oferecida aos "novos financistas", e também cauci- 
onando alguns empreendimentos dos gestores (Pavini et alii, 2004; D'Ambrosio e Vieira, 2003).

21. Na linguagem específica, trata-se de construir portfolios a partir de títulos com baixa covariância de risco, como, por exemplo, uma composição entre títulos de empresas exportadoras, cujos resultados dependem mais da evolução da taxa de câmbio, e títulos de redes de varejo popular, cujos resultados irão depender mais da evolução do mercado interno, supondo-se que taxa de câmbio e poder de compra das classes populares evoluam segundo tendências independentes.

22. Outro exercício interessante, e que certamente ajuda a conferir centralidade à figura de Fraga, seria contrastá-lo com seu antecessor no Banco Central, Gustavo Franco, que acabou se confinando em um papel social de zelote do neoliberalismo. Diante dos "excessos" deste último, nosso personagem central ganha ares de pessoa de bom senso, razoável e mesmo afável. Aliás, as mesmas reportagens que exaltam Fraga lembram que Franco é um indivíduo isolado, que não faz parte do grupo.

23. Aí aparece mais forte o contraste com Franco.

24. Extensos comentários e críticas dos colegas-filósofos de Goodman sobre o assunto, seguidos de réplicas e precisões do autor em McCormick (1996).

25. "Prática" aqui é um termo que se refere à eficácia do discurso nos limites internos do campo político. Se a oposição não encontra uma retórica para se contrapor ao discurso da situação, ela tende a desaparecer. Assim o discurso das câmaras pode ser considerado "prático" se consegue manter a operacionalidade política da oposição. Evidentemente, essa praticidade pode ou não ter correspondência com sua aplicação "concreta" no espaço econômico, mas esse problema só poderá ser realmente colocado quando e se a oposição virar governo. Sobre essa autonomização do discurso interno ao campo político, ver Bourdieu (1981).

26. Sobre as câmaras, ver Arbix e Zilbovicius (1997). Sobre a minha interpretação da importância do fenômeno para a trama cultural econômica, ver Grün (2003a).

27. Ver a entrevista de José Lopez Feijóo, então secretário-geral do Sindicato dos Metalúrgicos do $\mathrm{ABC}$, no endereço eletrônico: <http://www.oficinainforma.com.br/semana/leituras-20020119/02.htm>. Para a apresentação do evento pela Volkswagen, ver <http://www.volkswagen.com.br/fábricanovaanchieta>.

28. Sobre as repercussões do processo, ver, p. ex., a coluna de Luís Nassif, "A Estratégia da Volks" (Folha de S. Paulo, 15/6/2002).

29. O compromisso aparece de maneira mais clara na idéia de kaizen - a busca sistemática de redução de desperdício na atividade organizacional. A lógica industrial funcionando sem "predadores naturais" enfatiza a busca de eficiência por meio dos aumentos de escala, dando à redução do desperdício um status de simples detalhe. Ver, a respeito dos repertórios de argumentação de cada uma das lógicas, Boltanski e Thévenot (1991).

30. Sobre a lógica da ação dos agentes de comando industrial brasileiros e as contradições a que estão submetidos, ver Zilbovicius (1999).

31. Detalho as circunstâncias desse conflito cultural, que repõe os termos que já existiam no trabalho de Veblen (1921), em Grün (1999).

32. Menos importante para a zona do espaço social que estamos explorando no presente artigo, mas igualmente ou até mais importante no espaço social como um todo. 


\section{Roberto Grün}

33. No texto indicado, Douglas recupera a oposição "hierarquia x mercado", desenvolvida por Weber, e discute suas conseqüências cognitivas para o entendimento das disputas culturais nas sociedades capitalistas, em especial naquelas tocadas pelo neoliberalismo.

34. Ver <http:/ / www.lula.org.br/programadegoverno>, acessado em 25/7/2002.

35. Acompanhei os principais jornais naquele momento e não encontrei, nem nas páginas de reportagens nem nas colunas de cartas dos leitores, manifestações de apoio a Ciro Gomes ou a Garotinho quando de suas declarações antifinanceiras. A análise pode ser estendida e enriquecida pelo acompanhamento da tramitação da emenda que pretende alterar o sistema financeiro nacional, em especial na questão da fixação, ou não, de uma taxa de juros legal máxima - a "velha" questão da Lei da Usura, que teve algum destaque no início do governo Lula e depois desapareceu do noticiário (ver, p. ex., Oliveira, 2003).

36. É interessante lembrar a experiência nacional da Malásia, considerada a principal contraprova de um país que conseguiu se livrar da influência dos mercados financeiros internacionais e, conseqüentemente, da arbitragem. Ali, o repúdio à ação dos mercados financeiros aparece ao lado de uma retórica anti-semita e xenófoba (Cohen, no prelo). Podemos também acrescentar a própria história do fascismo "clássico" europeu, que tem em uma de suas matrizes o obreirismo antifinanceiro e anti-semita dos seguidores de Proudhon (Sternhell, 1984). Assim, ao observarmos a nossa pequena experiência doméstica nas eleições de 2002, o principal exemplo internacional dos nossos dias e a experiência histórica clássica, é difícil imaginar que a associação antiplutocracia e xenofobia e anti-semitismo seja fortuita, ainda que não determinística.

37. Sobre os constrangimentos sociais e tecnológicos que regem a produção e a manutenção dessa opinião padronizada, e a força desse consenso, ver Knorr Cetina e Bruegger (2002b).

38. Assim podemos conferir sentido às reiteradas declarações de Lula, conclamando os empresários a investir sem levar em conta as altas taxas de juros (ver, p. ex., Athias, 2004:B1).

39. Internacionalmente, a lógica da concertação, amparada nos conceitos de rede e de capital social, tenta afirmar-se como uma alternativa de ordem moderna distinta da financeira. Seus partidários começam com a explicação dos ciclos virtuosos produzidos na "III Itália" (Putnam et alii, 1993), chegando a generalizações que tentam dar conta do mundo econômico atual na sua totalidade, questionando a idéia do primado da lógica financeira na produção do laço social fundamental (Boltanski e Chiapello, 1999).

40. Ver, p. ex., as atas do seminário "Ipea Discute Arranjos Produtivos Locais", de 26-27 de agosto de 2003, no site da instituição. Segundo os organizadores: "Políticas públicas baseadas no conceito de arranjos produtivos locais têm sido desenhadas para promover o aumento das exportações, promover a redução das desigualdades regionais, fomentar sistemas locais de inovação e promover uma maior inclusão social" (<http://www.ipea.gov.br >).

41. É interessante notar que a FIESP e o SEBRAE fazem parte da constelação das entidades "corporativas", portanto ameaçadas pelo padrão de racionalidade imposto pela cultura financeira, tendo assim um interesse muito mais forte do que o comum 
em fazer deslanchar iniciativas que mostrem suas respectivas contribuições para a sociedade brasileira.

42. Não podemos esquecer do "maximalista" Gustavo Franco, a outra figura que equilibra a imagem positiva de Fraga. Franco parece ter mantido sua influência em circuitos conservadores tradicionais. Acompanhar a dança das imagens pode ser uma entrada excelente para a análise do substrato cultural que sobredetermina as esferas econômica e financeira.

43. Por exemplo, em O Globo, 27/2/2004: “Refinaria do Ceará: Aliás, no jantar com Lula, o príncipe Bandar (sempre acompanhado do polêmico amigo brasileiro Naji Nahas) prometeu que a saudita Aramco voltará a estudar o projeto de construção, em parceria com a Petrobras, de uma refinaria no Ceará."

44. Ainda que, pela lógica do sistema de forças simbólico, esse enquadramento seja pouco provável, já que qualquer "senão" no futuro acordo da Argentina com seus credores será alardeado como a prova cabal do quixotismo da atitude de desafio aos mercados financeiros internacionais.

\section{REFERÊNCIAS BIBLIOGRÁFICAS}

ABOLAFIA, M. (1996), Making Markets: Opportunism and Restraint on Wall Street. Cambridge, Mass., Harvard University Press.

AGLIETTA, M. e ORLÉAN, A. (2002), La Monnaie entre Violence et Confiance. Paris, Odile Jacob.

ANDERSON, P. (1999), “Câmaras Setoriais: Histórico e Acordos Firmados 1991-1995”. Textos para Discussão. Rio de Janeiro, IPEA.

ARBIX, G. e ZILBOVICIUS, M. (1997), De JK a FHC: A Reinvenção dos Carros. São Paulo, Scritta.

ARMSTRONG, P. (2002), "The Costs of Activity-Based Management". Accounting, Organizations and Society, vol. 27, nำ1, pp. 99-120.

ATHIAS, G. (2004), “Presidente Critica Empresariado Brasileiro em Discurso na Índia e Diz que É Preciso Diminuir Reclamações: 'Empresário Tem que Chorar Menos', Diz Lula". Folha de S. Paulo, 28 de janeiro.

BATISTA, R. (2003), “Lula Defende Expansão da Poupança pela Via dos Fundos de Pensão". Valor Econômico, 29 de maio.

BERGER, P. L. e LUCKMANN, T. (1966), The Social Construction of Reality; a Treatise in the Sociology of Knowledge. Garden City, NY, Doubleday.

BERNSTEIN, P. L. (1992), Capital Ideas: The Improbable Origins of Modern Wall Street. New York, The Free Press. 


\section{Roberto Grün}

BOLTANSKI, L. e CHIAPELLO, E. (1999), Le Nouvel Esprit du Capitalisme. Paris, Gallimard.

BOLTANSKI, L. e THÉVENOT, L. (1991), De la Justification: Les Économies de la Grandeur. Paris, Gallimard.

BOURDELAIS, P. (1993), Le Nouvel Âge de la Vieillesse: Histoire du Vieillissement de la Population. Paris, Odile Jacob.

BOURDIEU, J., HEILBRON, J. e REYNAUD, B. (2003), “Les Structures Sociales de la Finance". Actes de la Recherche en Sciences Sociales, nº 146-147, pp. 3-7.

BOURDIEU, P. (1981), “La Représentation Politique. Éléments pour une Théorie du Champ Politique". Actes de la Recherche en Sciences Sociales, no 36-37, pp. 3-24.

_. (1984), Homo Academicus. Paris, Les Éditions de Minuit.

. (1989), La Noblesse d'État: Grandes Écoles et Esprit de Corps. Paris, Les Éditions de Minuit.

. (1997), Méditations Pascaliennes. Paris, Seuil.

BOYER, R. (2002), La Croissance Début de Siècle: De l'Octet au Géne. Paris, A. Michel. (2003), “L'Anthropologie Économique de Pierre Bourdieu”. Actes de la Recherche en Sciences Sociales, $\mathrm{n}^{\circ}$ 150, pp. 65-78.

CALLON, M. (ed.). (1998), The Laws of the Markets. Oxford/Malden, Mass., Blackwell Publishers.

CARDOSO, J. L. (2002), "Confusion de Confusiones: Ethics and Options on Seventeenth-Century Stock Exchange Markets". Financial History Review, vol. 9, no2, pp.109-123.

CIARELLI, M. e FARID, J. (2002), “Ações Migram para os Estados Unidos: Mais da Metade dos Papéis das Principais Empresas Nacionais É Negociada nos EUA". O Estado de S. Paulo, 25 de fevereiro.

COHEN, B. (no prelo), “Capital Controls: Why Do Governments Hesitate?", in L. E. Armijo (ed.), Debating the Global Financial Architecture. New York, Suny Press.

COLWYN JONES, T. e DUGDALE, D. (2002), “The ABC Bandwagon and the Juggernaut of Modernity". Accounting, Organizations and Society, vol. 27, no 1, pp.121-163.

CVM - Comissão de Valores Mobiliários. (2002), Recomendações da CVM sobre Governança Corporativa. Rio de Janeiro, junho, p. 13.

D'AMBROSIO, D. e VIEIRA, C. (2003), “Fundos Multimercados Voltados para o Público de Alta Renda se Multiplicam em Velocidade Espantosa: Quase um Novo Produto É Lançado por Dia: Os Novos VIPS". Valor Econômico, 16 de outubro.

. (2004), “Independentes com Patrimônio de R\$1 Bi: Clube do Bilhão". Valor Econômico, 19 de janeiro.

DÁVILA, S. (2004), “'República do Leblon' Cresce e Aparece”. Folha de S. Paulo, 18 de janeiro. 
DIAS, L. (2000), “Realeza no Green: O que Acontece quando os Nobres da Economia e Finanças se Encontram entre uma Tacada e Outra". Istoé Dinheiro, ํㅡㄴ 172, 8 de dezembro.

DIMAGGIO, P. (2001), The Twenty-First-Century Firm: Changing Economic Organization in International Perspective. Princeton, NJ, Princeton University Press.

DOUGLAS, M. (1996), Thought Styles: Critical Essays on Good Taste. London, Thousand Oaks/Sage.

_ e NEY, S. (1998), Missing Persons: A Critique of the Social Sciences. Berkeley/New York, University of California Press/Russell Sage Foundation.

DUAILIBI, J. (2001), “Ex-ministro Mendonça de Barros Depõe na Justiça e Diz que Escuta Serviu a Vencedor no Leilão da Telebrás: Mendonça Liga Ex-diretor do BB a Grampo". Folha de S. Paulo, 26 de abril.

FAMA, E. F. (1980), "Agency Problems and the Theory of Firm". Journal of Political Economy, vol. 88 , no 2, pp. 288-307.

FELÍCIO, César. (2002), “Ciro e Serra Regionalizam Discurso e Votos: Candidato do PPS Ataca 'Baronato Paulista' e Tucano Faz Alusões ao 'Neocoronelismo' em sua Página na Internet". Valor Econômico, 2 de setembro.

FLIGSTEIN, N. (2001), The Architecture of Markets: An Economic Sociology of Twenty-First-Century Capitalist Societies. Princeton, Princeton University Press.

e FREELAND, R. (1995), “Theoretical and Comparative Perspectives on Corporate Organization". Annual Review of Sociology, 1o de janeiro, pp. 21-43.

FOLHA DE S. PAULO. (2002), “Garotinho Elege Bancos como Vilões e Diz que Quer Renegociar com FMI". Folha de S. Paulo, 15 de agosto.

_. (2003), "Saiba o que Significa Concertação, Palavra-Símbolo do Conselho". Folha de S. Paulo, online, 13 de fevereiro.

FROUD, J. (2003), "The Private Finance Initiative: Risk, Uncertainty and the State". Accounting, Organizations and Society, vol. 28, no 6, pp. 567-589.

_ , HASLAM, C., JOHAL, S. e WILLIAMS, K. (2000), "Shareholder Value and Financialization: Consultancy Promises, Management Moves". Economy and Society, vol. 29 , no 1 , pp. 80-110.

FUTEMA, F. (2004), “PT e PPS Fecham Aliança para Eleição da Cassi”. Folha de S. Paulo, 30 de janeiro.

GALBRAITH, J. K. (1967), The New Industrial State. Boston, Houghton Mifflin. (1998), The Affluent Society. Boston, Houghton Mifflin, NetLibrary Inc.

GALVÃO, F. (2004), “Saiba como Funcionam os Chamados Fundos de Recebíveis, o Novo Fenômeno do Mercado Financeiro no Brasil". Istoé Dinheiro, 17 de março.

GARCIA, M.-F. (1986), “La Construction Sociale d'un Marché Parfait: Le Marché au Cadran de Fontaines-en-Sologne". Actes de la Recherche en Sciences Sociales, nº 65, pp. 2-13.

GOODMAN, N. (1988), Ways of Worldmaking. Indianapolis, Hackett Pub. Co. 


\section{Roberto Grün}

GRÜN, R. (1999), “Modelos de Empresa, Modelos de Mundo: Sobre Algumas Características Culturais da Nova Ordem Econômica e da Resistência a Ela". Revista Brasileira de Ciências Sociais, vol. 14, no 41, pp. 121-140.

_. (2003a), "Atores e Ações na Construção da Governança Corporativa Brasileira". Revista Brasileira de Ciências Sociais, vol. 18, nº 52, pp. 121-143.

. (2003b), “A Promessa da 'Inserção Profissional Instigante' da Sociedade em Rede: A Imposição de Sentido e a sua Sociologia". Dados, vol. 46, no 1, pp. 5-37.

. (2003c), "Fundos de Pensão no Brasil do Final do Século XX: Guerra Cultural, Modelos de Capitalismo e os Destinos das Classes Médias". Mana, vol. 9, no 2, pp. 7-38.

GUEX, S. (2003), “La Politique des Caisses Vides. État, Finances Publiques et Mondialisation". Actes de la Recherche en Sciences Sociales, no 146-147, pp. 51-61.

HANDLER, J. (1996), Down from Bureaucracy: The Ambiguity of Privatization and Empowerment. Princeton, NJ, Princeton University Press.

KAPLAN, R. S. e NORTON, D. P. (1996), The Balanced Scorecard: Translating Strategy into Action. Boston, Mass., Harvard Business School Press.

KING, M. R. e SINCLAIR, T. J. (2003), “Private Actors and Public Policy: A Requiem for the New Basel Capital Accord". International Political Science Review, vol. 24, no 3, pp. 345-362.

KNORR CETINA, K. e BRUEGGER, U. (2002a), “Global Microstructures: The Virtual Societies of Financial Markets". American Journal of Sociology, vol. 107, no 4, pp. 905-950.

. (2002b), “Inhabiting Technology: The Global Lifeform of Financial Markets". Current Sociology, vol. 50, no 3, pp. 389-405.

KOTCHO, R. (1976), “Assim Vivem os Nossos Superfuncionários”. Estado de S. Paulo, $1^{\circ}$ de agosto.

LANE, C. (2003), “Changes in Corporate Governance of German Corporations: Convergence to the Anglo-American Model?". Competition and Change, vol. 7, no 2-3, pp. 79-100.

LEBARON, F. (2000), La Croyance Économique: Les Économistes entre Science et Politique. Paris, Seuil.

_. (2003), Le Savant, le Politique et la Mondialisation. Broissieux, Éditions du Croquant.

LEONEL, J. e TAVARES, Rita. (2003), “Fechado Acordo para Votar Mudança no Sistema Financeiro, Diz Petista". O Estado de S. Paulo, 26 de março.

LORDON, F. (2000a), Fonds de Pension, Piége à Cons?: Mirage de la Démocratie Actionnariale. Paris, Ed. Raisons d'Agir.

. (2000b), “La 'Création de Valeur' comme Rhétorique et comme Pratique. Généalogie et Sociologie de la 'Valeur Actionnariale'”. L'Année de la Régulation: Économie, Institutions, Pouvoirs, vol. 4, pp.117-170.

. (2002), La Politique du Capital. Paris, Odile Jacob. 
MACKENZIE, D. (2002), Opening the Black Box of Global Finance. Trabalho apresentado no workshop Approaches to Global Finance, University of Warwick, 6-7 de dezembro.

. (2003), "Long-Term Capital Management and the Sociology of Arbitrage". Economy and Society, vol. 32, no 3, pp. 349-380.

MARTINEZ, A. C. (2004), “A Parceria Público-Privado e o Governo Paulista”. Linha Direta, 27 de fevereiro.

MATTOS, M. (2001), “Lei das S.A.É Aprovada e já se Negociam Vetos à Proteção de Minoritários". Valor Econômico, 20 de setembro.

MCCORMICK, P. (1996), Starmaking Realism, Anti-realism, and Irrealism. Cambridge, Mass., MIT Press.

MURPHY, P. (2002), “Esquerda e Bovespa Fazem Aliança Estratégica: Para Presidente da Bolsa, 'Muro de Berlim Caiu' com a Inédita Visita de Lula ao Pregão". O Estado de S. Paulo, $1^{\circ}$ de setembro.

NIKONOFF, J. (1999), La Comédie des Fonds de Pension: Une Faillite Intellectuelle. Paris, Arléa.

NORONHA, E. G., GEBRIN, V. e ELIAS JR., J. (no prelo), “Explaining an Exceptional Wave of Strikes: From Authoritarian Brazil to Democracy". British Journal of Industrial Relations.

NORREKLIT, H. (2000), "The Balance on the Balanced Scorecard - A Critical Analysis of some of its Assumptions". Management Accounting Research, no 11, pp. 65-88.

. (2003), "The Balanced Scorecard: What Is the Score? A Rhetorical Analysis of the Balanced Scorecard". Accounting, Organizations and Society, vol. 28, no 6, pp. 591-619.

OECD. (2003), White Paper on Corporate Governance in Latin America. Paris, OECD.

OLIVEIRA, R. (2003), “Governo já Tem Proposta para Mudar o 192". Valor Econômico, 19 de fevereiro.

PAVINI, Angelo, VIEIRA, Catherine e MONTEIRO, Luciana. (2004), “Gestoras Independentes Lançam Carteiras Arriscadas. Nova Safra de Fundos". Valor Econômico, 17 de fevereiro.

PENSO DE LA VEGA, J. (1977), Confusion de Confusiones: Diálogos Curiosos entre un Philósopho Agudo, un Mercader Discreto, y un Accionista Erudito. Valencia, Saetabis.

PERROW, C. (1990), “Economic Theories of Organization”, in P. Dimaggio (ed.), Structures of Capital: The Social Organization of the Economy. Cambridge, UK/New York, Cambridge University Press.

POLANYI, K. (2001) [1944], The Great Transformation: The Political and Economic Origins of our Time. Boston, Beacon Press.

PORTER, M. E. (1985), Competitive Advantage: Creating and Sustaining Superior Performance. New York/London, The Free Press/Collier Macmillan.

POWELL, W. W. e DIMAGGIO, P. (1991), The New Institutionalism in Organizational Analysis. Chicago, University of Chicago Press. 


\section{Roberto Grün}

PUTNAM, R. D., LEONARDI, R. e NANETTI, Raffaella Y. (1993), Making Democracy Work: Civic Traditions in Modern Italy. Princeton, NJ, Princeton University Press.

ROLLI, C. e FERNANDES, Fátima. (2004), “Proposta de Fortalecer as Centrais e Limitar Ações dos Sindicatos É Criticada por Especialistas; Direitos Podem Ser Negociados". Folha de S. Paulo, $1^{\text {o }}$ de março.

SANTOS, C. (2001), "PF Investiga Suposta Corrupção entre Consórcio Telemar e Ex-diretor do BB". Folha de S. Paulo, 27 de setembro.

SAUVIAT, C. (2001), “Syndicats et Marchés Financiers: Bilan et Limites des Stratégies Nord-américaines. Quelle Valeur d'Exemple pour les Syndicats en Europe?". Revue de l'IRES, vol. 36, no 2 .

SCHUMPETER, J. A. (1991), The Economics and Sociology of Capitalism. Princeton, NJ, Princeton University Press.

SEABRA, C. (2002), "Ciro Gomes Compara Mercado Financeiro à Escravatura". O Globo, 31 de agosto.

STERNHELL, Z. (1984), La Droite Révolutionnaire, 1885-1914: Les Origines Françaises du Fascisme. Paris, Seuil.

STREECK, W. e YAMAMURA, K. (2001), The Origins of Nonliberal Capitalism: Germany and Japan in Comparison. Ithaca, NY, Cornell University Press.

THOMPSON, E. P. (1993), Customs in Common. New York, New Press.

THOMPSON, P. (1997), “The Pyrrhic Victory of Gentlemanly Capitalism: The Financial Elite of the City of London, 1945-90, Part 2". Journal of Contemporary History, vol. 32, no 4 , pp. 427-440.

TROSTER, R. L. (2004), “Conspiração dos Bancos”. Folha de S. Paulo, 26 de março.

USEEM, M. (1993), Executive Defense: Shareholder Power and Corporate Reorganization. Cambridge, Mass., Harvard University Press.

(1996), Investor Capitalism: How Money Managers are Changing the Face of Corporate America. New York, Basic Books.

VEBLEN, T. (1921), The Engineers and the Price System. New York, B. W. Huebsch, Inc.

VITOLS, S. (2002), “Shareholder Value, Management Culture and Production Regimes in the Transformation of the German Chemical-Pharmaceutical Industry". Competition and Change, vol. 6, no 3, pp. 309-325.

WEAVER, M. (2003), “PFI: The Issue Explained”. The Guardian, Londres, 15 de janeiro.

ZILBOVICIUS, M. (1999), Modelos para a Produção, Produção de Modelos: Gênese, Lógica e Difusão do Modelo Japonês de Organização da Produção. São Paulo, FAPESP / Annablume. 


\begin{abstract}
Recent Trends in the Financial Field in Brazil and Some Impacts on the Political Scenario

During the last decade Brazil has witnessed the expansion and differentiation of its financial field, with a major impact on society and the composition of its elites. I analyze this process based on data concerning the new players and the instruments they disseminate in companies and other organizations in Brazilian society. These include both financial instruments per se and organizational tools based on the same logic. I seek to demonstrate that the quest for legitimacy for new players and instruments has led to a new cultural judgment on what constitutes society's "general interest", which drastically constrains action by the different governments and partially explains the paradoxes faced by the Lula Administration in its first year.
\end{abstract}

Key words: economic sociology; sociology of finance; arbitration; cultural warfare; economic culture

\title{
RÉSUMÉ \\ L'Évolution Récente de l'Espace Financier au Brésil et ses Répercussions sur la Scène Politique
}

Dans la dernière décennie, le Brésil a connu un essor et des changements dans son espace financier qui ont provoqué un grand impact dans la société et la composition de ses élites. On examine ici ce processus à partir de données concernant les nouveaux acteurs et les instruments qu'ils diffusent dans les entreprises et autres organisations de la société brésilienne. Leurs instruments sont non seulement d'ordre directement financier mais aussi d'ordre organisationnel inspirés par la même logique. On cherche à montrer que la quête de légitimité des nouveaux agents et instruments finit par créer un nouvel arbitraire culturel à propos de ce qui est "l'intérêt général" de la société; ce facteur, qui gêne fortement l'action des différents gouvernements, saurait expliquer, en partie, les paradoxes auxquels le gouvernement Lula doit faire face dans sa première année d'exercice.

Mots-clé: sociologie économique; sociologie des finances; arbitrage; guerre culturelle; culture économique 